\title{
Primary and secondary aerosols in Beijing in winter: sources, variations and processes
}

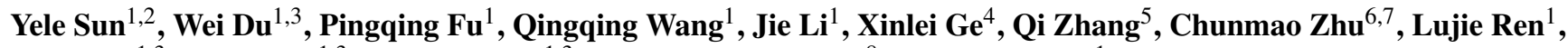 \\ Weiqi Xu ${ }^{1,3}$, Jian Zhao ${ }^{1,3}$, Tingting Han ${ }^{1,3}$, Douglas R. Worsnop ${ }^{8}$, and Zifa Wang ${ }^{1}$ \\ ${ }^{1}$ State Key Laboratory of Atmospheric Boundary Layer Physics and Atmospheric Chemistry, \\ Institute of Atmospheric Physics, Chinese Academy of Sciences, Beijing 100029, China \\ ${ }^{2}$ Center for Excellence in Urban Atmospheric Environment, Institute of Urban Environment, \\ Chinese Academy of Sciences, Xiamen 361021, China \\ ${ }^{3}$ College of Earth Sciences, University of Chinese Academy of Sciences, Beijing 100049, China \\ ${ }^{4}$ School of Environmental Science and Engineering, Nanjing University of Information \\ Science \& Technology, Nanjing 210044, China \\ ${ }^{5}$ Department of Environmental Toxicology, University of California, 1 Shields Ave., Davis, CA 95616, USA \\ ${ }^{6}$ Institute of Low Temperature Science, Hokkaido University, Sapporo 060-0819, Japan \\ ${ }^{7}$ CMA Key Laboratory of Aerosol-Cloud-Precipitation, Nanjing University of Information \\ Science and Technology, Nanjing 210044, China \\ ${ }^{8}$ Aerodyne Research, Inc., Billerica, MA 01821, USA
}

Correspondence to: Yele Sun (sunyele@mail.iap.ac.cn)

Received: 23 March 2016 - Published in Atmos. Chem. Phys. Discuss.: 29 March 2016

Revised: 23 June 2016 - Accepted: 23 June 2016 - Published: 11 July 2016

\begin{abstract}
Winter has the worst air pollution of the year in the megacity of Beijing. Despite extensive winter studies in recent years, our knowledge of the sources, formation mechanisms and evolution of aerosol particles is not complete. Here we have a comprehensive characterization of the sources, variations and processes of submicron aerosols that were measured by an Aerodyne high-resolution aerosol mass spectrometer from 17 December 2013 to 17 January 2014 along with offline filter analysis by gas chromatography/mass spectrometry. Our results suggest that submicron aerosols composition was generally similar across the winter of different years and was mainly composed of organics $(60 \%)$, sulfate $(15 \%)$ and nitrate $(11 \%)$. Positive matrix factorization of high- and unit-mass resolution spectra identified four primary organic aerosol (POA) factors from traffic, cooking, biomass burning (BBOA) and coal combustion (CCOA) emissions as well as two secondary OA (SOA) factors. POA dominated OA, on average accounting for $56 \%$, with CCOA being the largest contributor $(20 \%)$. Both CCOA and BBOA showed distinct polycyclic aromatic hydrocarbons (PAHs) spectral signatures, indicating that PAHs
\end{abstract}

in winter were mainly from coal combustion (66\%) and biomass burning emissions $(18 \%)$. BBOA was highly correlated with levoglucosan, a tracer compound for biomass burning $\left(r^{2}=0.93\right)$, and made a considerable contribution to OA in winter $(9 \%)$. An aqueous-phase-processed SOA (aqOOA) that was strongly correlated with particle liquid water content, sulfate and S-containing ions (e.g. $\mathrm{CH}_{2} \mathrm{SO}_{2}^{+}$) was identified. On average aq-OOA contributed $12 \%$ to the total $\mathrm{OA}$ and played a dominant role in increasing oxidation degrees of OA at high $\mathrm{RH}$ levels $(>50 \%)$. Our results illustrate that aqueous-phase processing can enhance SOA production and oxidation states of OA as well in winter. Further episode analyses highlighted the significant impacts of meteorological parameters on aerosol composition, size distributions, oxidation states of OA and evolutionary processes of secondary aerosols. 


\section{Introduction}

Air pollution caused by high concentration of fine particles $\left(\mathrm{PM}_{2.5}\right.$, particles with aerodynamic diameter less than $\left.2.5 \mu \mathrm{g} \mathrm{m}^{-3}\right)$ is of great concern in densely populated megacities due to its harmful effects to public health (Cao et al., 2012; Madaniyazi et al., 2015). Although the annual average concentration of $\mathrm{PM}_{2.5}$ in Beijing decreased from $89.5 \mu \mathrm{g} \mathrm{m}^{-3}$ in 2013 to $80.6 \mu \mathrm{g} \mathrm{m}^{-3}$ in 2015 , it is still far above the Chinese National Ambient Air Quality Standard (CNAAQS, $35 \mu \mathrm{g} \mathrm{m}^{-3}$ as an annual average). Mitigating air pollution in Beijing remains a great challenge (Zhang et al., 2012, 2016), not only because of its complex sources and processes, for instance local emissions vs. regional transport and primary emissions vs. secondary formation, but also due to the complex interactions between meteorology and atmospheric aerosols (Ding et al., 2013, 2016; Petäjä et al., 2016). Therefore, an understanding of the sources and processes of atmospheric aerosols in the megacity of Beijing is important for providing mitigation strategies related to air quality to the northern pan-Eurasian and Chinese societies, and it also contributes to the Earth system science and climate policy (Kulmala et al., 2015).

Extensive studies on the basis of various offline and online techniques have been conducted in Beijing in recent years to investigate the concentrations and sources of fine particles. The results show consistently higher PM levels in winter than in other seasons, mainly due to coal combustion emissions in the heating season (Sun et al., 2013b; Zhang et al., 2013; Sun et al., 2014; Liang et al., 2015; Liu et al., 2015). Receptor model analyses, e.g. positive matrix factorization (PMF) and chemical mass balance (CMB) further confirmed the importance of coal combustion emissions in particulate matter (PM) pollution in winter (Zheng et al., 2005; Zhang et al., 2013). For example, coal combustion aerosol was found to be one of the most important primary components, on average contributing $20-33 \%$ of the total organic aerosol (OA) mass in winter (Sun et al., 2013b, 2014; Wang et al., 2015; $\mathrm{Hu}$ et al., 2016). However, the contributions of traffic emissions are highly uncertain. For instance, Zhang et al. (2013) reported a contribution of $4 \%$ for traffic emissions, whereas Tian et al. (2016) showed a much higher contribution (19\%) in Beijing. The reasons for such differences are not clear yet. More recently, many studies highlight the importance of secondary aerosols in the formation of severe haze episodes in megacities (Liu et al., 2013; X. J. Zhao et al., 2013; Huang et al., 2014; Sun et al., 2014; Yang et al., 2015). Because secondary aerosols are mainly formed over regional scales, their dominance in PM demonstrates the importance of regional transport in the formation of severe haze episodes in northern China (Sun et al., 2014; Z. Wang et al., 2014; Li et al., 2015; Zheng et al., 2015). Such conclusions are further supported by the Asia-Pacific Economic Cooperation (APEC) studies when secondary aerosol species from regional trans- port showed the largest reductions due to emission controls in Beijing and surrounding regions (Sun et al., 2016).

The rapid changes in source and evolution of severe haze episodes have also been studied using various state-of-the-art online instruments, particularly the Aerodyne aerosol mass spectrometer (AMS), which is capable of quantifying sizeresolved non-refractory submicron aerosol composition at a high time resolution (Canagaratna et al., 2007). The PMF analysis of aerosol mass spectrometer (PMF-AMS) data illustrated the rapid variations of OA factors from different sources and processes. Primary OA (POA), such as trafficrelated hydrocarbon-like OA (HOA), cooking OA (COA), coal combustion OA (CCOA) and biomass burning OA (BBOA), generally showed strong diurnal variations influenced by local source emissions (Huang et al., 2010; J. Sun et al., 2010; Sun et al., 2012, 2013b; Zhang et al., 2014; Sun et al., 2015; Xu et al., 2015; Elser et al., 2016; Hu et al., 2016), whereas secondary organic aerosols (SOA) and secondary inorganic aerosols (SIA) were found to accumulate rapidly within days and contribute most to the severe haze pollution (Sun et al., 2014; Zheng et al., 2015). Recent lab and field studies also indicated that heterogeneous reactions under high $\mathrm{RH}$ and $\mathrm{NO}_{x}$ levels might have played important roles in secondary aerosol formation and can increase the PM levels substantially (He et al., 2014; Y. Wang et al., 2014; Quan et al., 2015; Xie et al., 2015).

Although submicron aerosol composition in Beijing has been relatively well characterized using aerosol mass spectrometry during the last decade (Huang et al., 2010; J. Sun et al., 2010; Sun et al., 2012, 2013b; Zhang et al., 2014; Sun et al., 2015; Xu et al., 2015; Elser et al., 2016; Hu et al., 2016), the contributions of primary sources to PM pollution and the evolutionary processes of SOA and its oxidation properties, particularly under high RH conditions, remain less understood. For example, BBOA was mixed within other primary OA factors in previous winter PMF-ACSM analysis due to the limited sensitivity of the ACSM (Sun et al., 2013b; Jiang et al., 2015). The recent two HR-AMS studies also showed substantially different OA composition in different winters in Beijing (Elser et al., 2016; Hu et al., 2016). Elser et al. (2016) found that CCOA contributed approximately $50 \%$ of the total OA mass in $\mathrm{PM}_{2.5}$, whereas $\mathrm{Hu}$ et al. (2016) reported an average contribution of $24 \%$ to $\mathrm{OA}$ in $\mathrm{PM}_{1}$. The reasons for such differences are not clear yet, although the different sized cut-offs might be one of them. In addition, the aqueousphase processing of $\mathrm{OA}$ at low temperatures in winter remains uncertain. While it has been suggested to be an important formation pathway of SOA (Ge et al., 2012b; Lin et al., 2014), Sun et al. (2013a) found that aqueous-phase processing appeared not to significantly enhance SOA and oxidation degree of OA in winter in Beijing. Most importantly, source emissions in northern China are undergoing significant changes since the implementation of the Atmospheric Pollution Prevention and Control Action Plan on 10 September 2013. As a response, the sources and processes of at- 
mospheric aerosols might have significant changes and vary substantially in different years. Thus, continuous characterization of aerosol particles in different years in Beijing is of importance for future validation of the response of aerosol chemistry-to-emission controls.

In this study, an Aerodyne high-resolution time-of-flight AMS (AMS hereafter) along with various collocated online instruments were deployed at an urban site in Beijing for real-time characterization of the sources and processes of aerosol particles during winter 2013-2014. Three-hour filter samples were also collected and analysed for molecular markers with gas chromatography/mass spectrometry (GC/MS). The aerosol composition, size distributions and diurnal variations are comprehensively investigated and also compared with the results in previous studies. The sources of OA are investigated by PMF-AMS analysis of both high mass resolution (HMR) and unit mass resolution (UMR) spectra, together with molecular marker analysis. The evolution processes of OA, particularly aqueous-phase processing of SOA and its oxidation degrees, are elucidated, and the impacts of meteorological parameters on severe haze formation are demonstrated.

\section{Experimental methods}

\subsection{Sampling site and instrumentation}

The AMS was deployed at an urban site in Beijing, i.e. Institute of Atmospheric Physics (IAP), Chinese Academy of Sciences, which was described in detail in Sun et al. (2012) from 17 December 2013 to 17 January 2014. The sampling site is subject to multiple local influences, including cooking emissions from nearby restaurants, traffic emissions from traffic, roads and Jingzang highway and sporadic coal combustion emissions from residential heating. During this study period, ambient aerosol particles were first drawn inside the sampling room at a flow of $10 \mathrm{~L} \mathrm{~min}^{-1}$, of which $\sim 0.1$ was isokinetically sampled into the AMS. The AMS was then operated by alternating the mass-sensitive $\mathrm{V}$-mode and the high mass resolution $\mathrm{W}$-mode every 2 min. The AMS was calibrated for ionization efficiency with $350 \mathrm{~nm}\left(D_{m}\right)$ ammonium nitrate particles following the standard protocols (Jayne et al., 2000; Jimenez et al., 2003), and the relative ionization efficiency (RIE) of ammonium (=5.0) was also determined.

The gaseous species were measured by a range of gas analysers (Thermo Scientific), including $\mathrm{CO}$ (model 48i), $\mathrm{NO} / \mathrm{NO}_{y}($ model $42 i), \mathrm{O}_{3}(\operatorname{model} 49 i)$ and $\mathrm{SO}_{2}(\operatorname{model} 43 i)$, and the meteorological parameters (winds, temperature and relative humidity) were obtained from the Beijing $325 \mathrm{~m}$ meteorological tower nearby. All the data in this study are reported at ambient temperature and pressure conditions in Beijing Time (BT), which equals Coordinated Universal Time (UTC) plus $8 \mathrm{~h}$.
Three-hour $\mathrm{PM}_{1.0}$ samples were collected using an air sampler (Zambelli, Italy) at a flow rate of $38.3 \mathrm{~L} \mathrm{~min}^{-1}$ with quartz filters $(47 \mathrm{~mm}$ diameter, Pallflex), which were precombusted at $450^{\circ} \mathrm{C}$ for $6 \mathrm{~h}$ over 6-9 January 2014 . Field blanks were collected by placing filters onto the filter holder for a few minutes without pumping before and after the campaign. After sampling, each aerosol or blank filter was wrapped individually with aluminum foil and stored at $-18^{\circ} \mathrm{C}$ in darkness prior to analysis.

\subsection{Chemical analysis}

Aliquots of filter quartz samples were first extracted with dichloromethane/methanol $(2: 1 ; v / v)$, and then concentrated by a rotary evaporator under vacuum after filtration. After dryness with pure nitrogen gas, the extracts were reacted with N,O-bis-(trimethylsilyl)trifluoroacetamide to form derivatives for subsequent GC/MS analysis. In this study, 24 molecular compounds were quantified, including sugar compounds (levoglucosan, galactosan, mannosan), 4hydroxybenzoic acid, vanillin, 2-methyltetrols etc. A more detailed filter pretreatment and GS/MS analysis is given in Fu et al. (2008).

\subsection{AMS data analysis}

The AMS data were analysed for the mass concentrations and size distributions of non-refractory submicron aerosol $\left(\mathrm{NR}-\mathrm{PM}_{1}\right)$ species using high-resolution data analysis software package PIKA (Sueper, 2014). A collection efficiency (CE) of 0.5 was applied to the entire data set to compensate for the incomplete detection of the AMS because (1) aerosol particles were dried by a silica gel dryer, (2) aerosol particles were slightly acidic (Fig. S1 in the Supplement), yet not high enough to affect CE substantially, and (3) the mass fraction of $\mathrm{NH}_{4} \mathrm{NO}_{3}$ was smaller than 0.4 for the entire study (Matthew et al., 2008; Middlebrook et al., 2012). Elemental analysis (EA) was performed on high-resolution mass spectra of OA using the software APES (Aiken et al., 2008). The elemental ratios, including oxygen-to-carbon $(\mathrm{O} / \mathrm{C})$, hydrogento-carbon $(\mathrm{H} / \mathrm{C})$, nitrogen-to-carbon $(\mathrm{N} / \mathrm{C})$ and organicmass to organic carbon $(\mathrm{OM} / \mathrm{OC})$ ratios, were determined with the Aiken-Ambient (A-A) (Aiken et al., 2008) method and the recently updated parameterization named ImprovedAmbient (I-A) (Canagaratna et al., 2015). As shown in Fig. S2, the $\mathrm{O} / \mathrm{C}$ and $\mathrm{H} / \mathrm{C}$ ratios are on average 28 and $11 \%$ higher than those derived from the A-A method. The elemental ratios reported in this study are obtained from the I-A method unless otherwise stated.

Positive matrix factorization (Paatero and Tapper, 1994) was performed on high resolution mass spectra of V-mode and $\mathrm{W}$-mode to retrieve potential OA factors from different sources. Because of the limited mass resolution of AMS, PMF analysis was limited to $m / z$ 150. It should be noted that, for $m / z, 120-150$, only major fragment ions were included in 
the PMF analysis. The data and error matrices were treated according to the procedures detailed in DeCarlo et al. (2010). The PMF solution was then evaluated using a PMF Evaluation Toolkit written in Igor Pro (Ulbrich et al., 2009) following the procedures described in Zhang et al. (2011). After a careful evaluation of the PMF results, we found that the six factor solution at $f_{\text {peak }}=0$ can be well interpreted. The six factors are four POA factors, including HOA, COA, BBOA and CCOA, and two SOA factors, including an oxygenated OA (OOA) and an aqueous-OOA (aq-OOA). As indicated by the diagnostic plot in Fig. S3, the contributions of OA factors were fairly stable across different $f_{\text {peak }}$ values. Figure S4 shows the correlations of six OA factors with other tracers. It is clear that each OA factor was correlated with specific tracers, for instance, HOA vs. $\mathrm{NO}_{x}\left(r^{2}=0.73\right)$, CCOA vs. PAHs $\left(r^{2}=0.92\right)$, COA vs. $\mathrm{C}_{6} \mathrm{H}_{10} \mathrm{O}^{+}\left(r^{2}=0.76\right)$, BBOA vs. $\mathrm{C}_{2} \mathrm{H}_{4} \mathrm{O}_{2}^{+}\left(r^{2}=0.65\right)$, OOA vs. $\mathrm{CO}_{2}^{+}\left(r^{2}=0.89\right)$ and aqOOA vs. SIA $\left(r^{2}=0.92\right)$. We also compared the PMF results between $\mathrm{V}$-mode and $\mathrm{W}$-mode. As shown in Fig. S5, the time series of six OA factors were highly correlated between the two modes. In this study, we further performed PMF analysis on UMR mass spectra of V-mode between $\mathrm{m} / \mathrm{z} 12$ and 350 . Such an analysis can keep the most important PAHs information (Dzepina et al., 2007) for a better source apportionment despite several recent PMF-HMR analyses to $\mathrm{m} / z 200$ (Hu et al., 2013, 2016). The PMF-UMR solution was also evaluated in the same way as that of PMF-HMR. As indicated in Fig. S6, the mass spectra of six OA factors from PMF-UMR were similar to those from PMF-HMR $\left(r^{2}=0.86-0.98\right)$.

\subsection{Liquid water content}

Liquid water content associated with inorganic species was predicted using a ISORROPIA-II model (Nenes et al., 1998; Fountoukis and Nenes, 2007) with AMS aerosol composition and meteorological parameters (temperature and relative humidity) as input. The ISORROPIA-II model then calculated the composition and phase state of a $\mathrm{K}^{+}-\mathrm{Ca}^{2+}-\mathrm{Mg}^{2+}-\mathrm{NH}_{4}^{+}$ $-\mathrm{Na}^{+}-\mathrm{SO}_{4}^{2-}-\mathrm{NO}_{3}^{-}-\mathrm{Cl}^{-}-\mathrm{H}_{2} \mathrm{O}$ in thermodynamic equilibrium with gas-phase precursors.

\section{Results and discussion}

\subsection{Mass concentrations and compositions}

Figure 1 shows the time series of meteorological parameters, gaseous species and NR-PM 1 aerosol species for the entire study period. The NR-PM 1 species varied dramatically throughout the study. The average NR-PM 1 mass concentration was $64 \pm 59 \mu \mathrm{g} \mathrm{m}^{-3}$, which is similar to that observed during winter 2011-2012 (Sun et al., 2013b), yet $32 \%$ lower than that measured during the severe pollution month of January 2013 (Zhang et al., 2014). As shown in Fig. 2b, the average NR-PM 1 concentrations in Beijing var- ied from 50 to $94 \mu \mathrm{g} \mathrm{m}^{-3}$ since 2006 , and even remained at relatively high levels in $2014\left(51-67 \mathrm{~g} \mathrm{~m}^{-3}\right)$ after the release of Atmospheric Pollution Prevention and Control Action Plan on 10 September 2013. The concentration levels of $\mathrm{PM}$ are much higher than the annual CNAAQS of $35 \mu \mathrm{g} \mathrm{m}^{-3}$, indicating that the air pollution in Beijing is still severe during all seasons (Sun et al., 2015).

Organics constituted a major fraction of NR-PM 1 , on average accounting for $60 \%$ during this study. The dominance of organics is generally consistent with previous winter studies in Beijing, which showed that $50-60 \%$ of NR-PM 1 were organics (Sun et al., 2013b; Zhang et al., 2014; Sun et al., 2015; Zhang et al., 2015; Hu et al., 2016). The contribution of organics to NR-PM 1 in winter was much higher than that during other seasons $(\sim 30-40 \%)$, which was primarily due to substantial emissions from coal combustion (Sun et al., 2013b; Elser et al., 2016; Hu et al., 2016). This is further supported by a large enhancement of chloride contribution from $\sim 1 \%$ in summer to $4-6 \%$ in winter. Sulfate was the second largest component $(15 \%)$ and is comparable to nitrate $(11 \%)$. SIA showed much lower contributions to NR$\mathrm{PM}_{1}$ in winter compared to summer due to weaker photochemical processing associated with low $\mathrm{O}_{3}(5.6 \pm 7.3 \mathrm{ppb})$. Aerosol composition of NR-PM 1 varied substantially across the entire study, yet appeared to be strongly affected by $\mathrm{RH}$. While the entire study period was characterized by low $\mathrm{RH}$ ( $<40 \%, 77 \%$ of the time), five episodes with RH $>40 \%$ were also observed (E1-E5 in Fig. 1). The periods with high RH levels were clearly characterized by high contributions of SIA, particularly sulfate. Indeed, the sulfate concentration often rapidly exceeded nitrate as the $\mathrm{RH}$ increased to above $40 \%$, indicative of aqueous-phase production during wintertime (Sun et al., 2013a, 2014; Quan et al., 2015). As indicated in Fig. $3 \mathrm{a}, \mathrm{SO}_{4} / \mathrm{NO}_{3}$ ratios showed evident increases as a function $\mathrm{RH}$ at high PM loading periods $\left(>30 \mu \mathrm{g} \mathrm{m}^{-3}\right)$. As $\mathrm{RH}$ was $>40 \%$, the ratios of $\mathrm{SO}_{4} / \mathrm{NO}_{3}$ exceeded 1 most of the time, demonstrating a more important role for sulfate in SIA during high $\mathrm{RH}$ periods. As a comparison, nitrate was more significant at low RH levels $(<30 \%)$. These results elucidate different mechanisms in the formation of sulfate and nitrate, which are mainly driven by aqueous-phase and photochemical production, respectively, in winter. Considering that aerosol particles were slightly acidic, as indicated by the average ratio $(0.69)$ of measured $\mathrm{NH}_{4}^{+}$to predicted $\mathrm{NH}_{4}^{+}$that requires to fully neutralize sulfate, nitrate and chloride (Zhang et al., 2007), sulfate in this study mainly existed in the form of $\left(\mathrm{NH}_{4}\right)_{2} \mathrm{SO}_{4}$ and $\mathrm{NH}_{4} \mathrm{HSO}_{4}$. We also noticed higher $\mathrm{SO}_{4} / \mathrm{NO}_{3}$ ratios during periods with lower aerosol loadings $\left(<30 \mu \mathrm{g} \mathrm{m}^{-3}\right)$. One reason is that air masses were dominantly from the north-north-west with much lower $\mathrm{NO}_{x}$ emissions compared to the megacities in eastern China (B. Zhao et al., 2013). In addition, the shorter lifetime of nitrate compared to sulfate might also have played a role during the long-range transport from the north-north-west to Bei- 


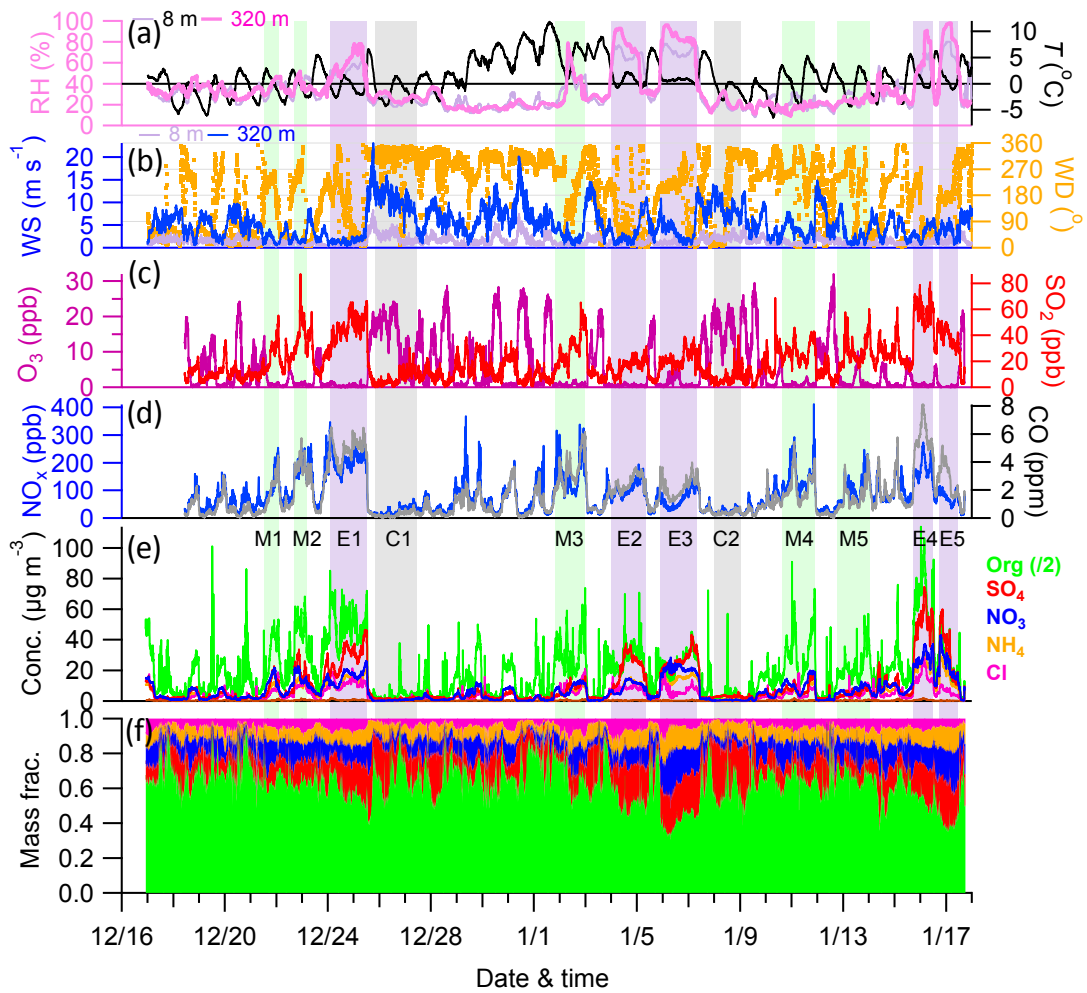

Figure 1. Time series of (a) relative humidity (RH) and temperature ( $T$ ), (b) wind speed (WS) and wind direction (WD), (c) $\mathrm{O}_{3}$ and $\mathrm{SO}_{2}$, (d) $\mathrm{CO}$ and $\mathrm{NO}_{x}$, (e) mass concentrations of $\mathrm{NR}-\mathrm{PM}_{1}$ species and (f) mass fractions of NR-PM $\mathrm{P}_{1}$ species for the entire study period. In addition, five episodes with relatively high RH levels (E1-E5), five episodes with moderately high RH levels (M1-M5), and two clean periods $(\mathrm{C} 1, \mathrm{C} 2)$ are marked for further discussion.

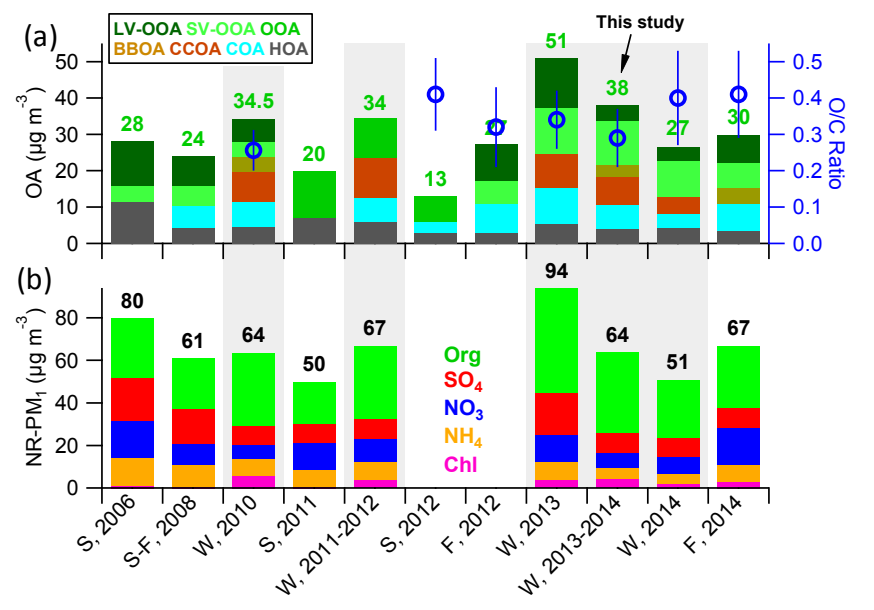

Figure 2. Average chemical composition of (a) organic aerosols and (b) NR-PM 1 in the megacity of Beijing measured by aerosol mass spectrometers. Also shown in panel (a) is the oxygen-to-carbon (O / C) ratio of organic aerosol for each study. The $\mathrm{O} / \mathrm{C}$ was calculated using the A-A method (Aiken et al., 2008). A more detailed description of the data is presented in Table S1. jing. Figure $3 \mathrm{~b}$ shows the size dependence of $\mathrm{SO}_{4} / \mathrm{NO}_{3}$ ratios during five episodes with high RH levels $(>40 \%)$ and five episodes with low RH levels $(<40 \%)$. It is clear that $\mathrm{SO}_{4} / \mathrm{NO}_{3}$ ratios at high $\mathrm{RH}$ levels were consistently higher than those at low RH levels across different size ranges, further supporting the importance of aqueous-phase processing in the formation of sulfate. Also, $\mathrm{SO}_{4} / \mathrm{NO}_{3}$ ratios showed clear increases as a function of particle sizes, likely indicating the different formation processes of sulfate and nitrate in different size ranges. Considering that large accumulation mode particles are generally more aged than smaller particles (Zhang et al., 2005), results here might indicate that nitrate mainly formed via photochemical production played a more important role in SIA at smaller sizes, whereas sulfate that formed over regional scales was more significant in accumulation mode particles.

\subsection{Diurnal cycles and size distributions}

The diurnal cycles varied differently among different NR$\mathrm{PM}_{1}$ species. As shown in Fig. 4a, organics were characterized by two peaks occurring at noon and evening time. Such a diurnal pattern influenced by cooking emissions at meal times has been observed during all seasons in Beijing (Huang et al., 2010; J. Sun et al., 2010; Sun et al., 2012; 

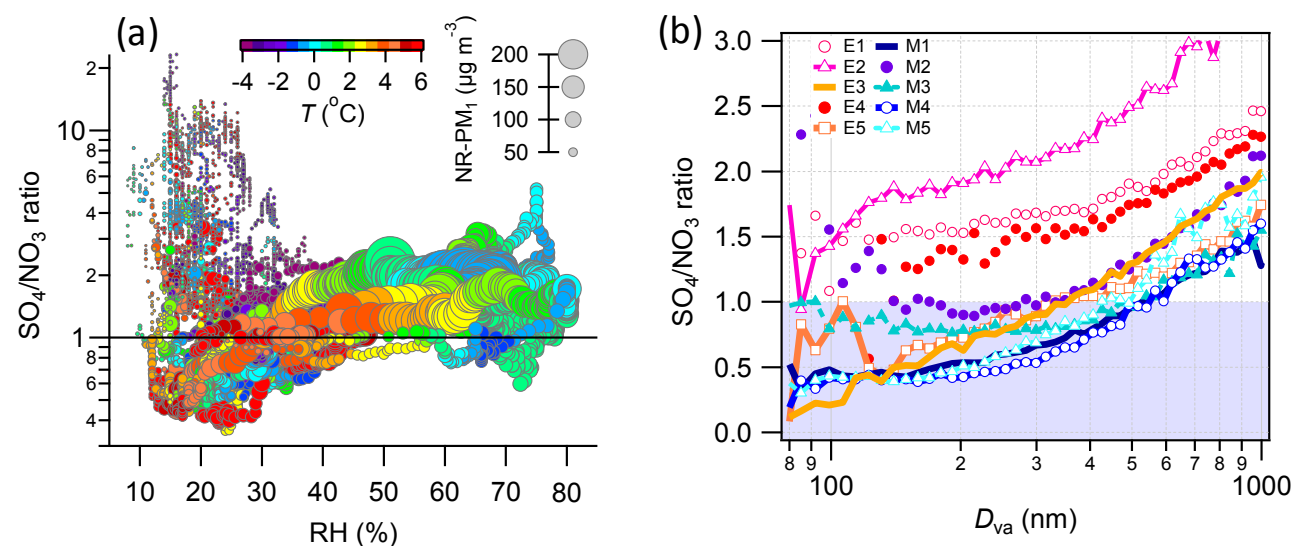

Figure 3. (a) Variations of $\mathrm{SO}_{4} / \mathrm{NO}_{3}$ ratios as a function of $\mathrm{RH}$, (b) size-resolved $\mathrm{SO}_{4} / \mathrm{NO}_{3}$ ratio during five episodes (E1-E5) with high RH levels (> $40 \%)$ and five episodes (M1-M5) with low RH levels $(<40 \%)$.

(a)

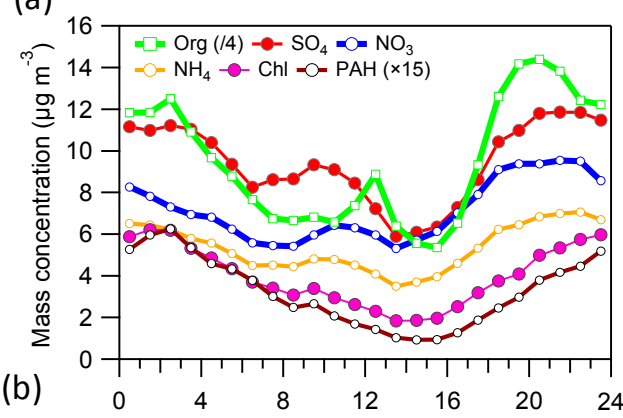

(b)

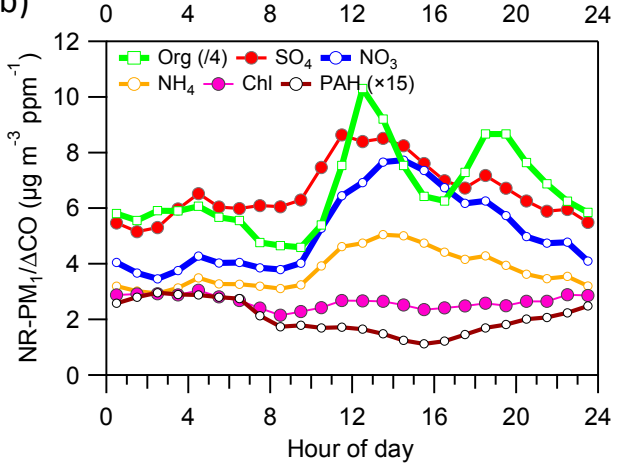

(c)
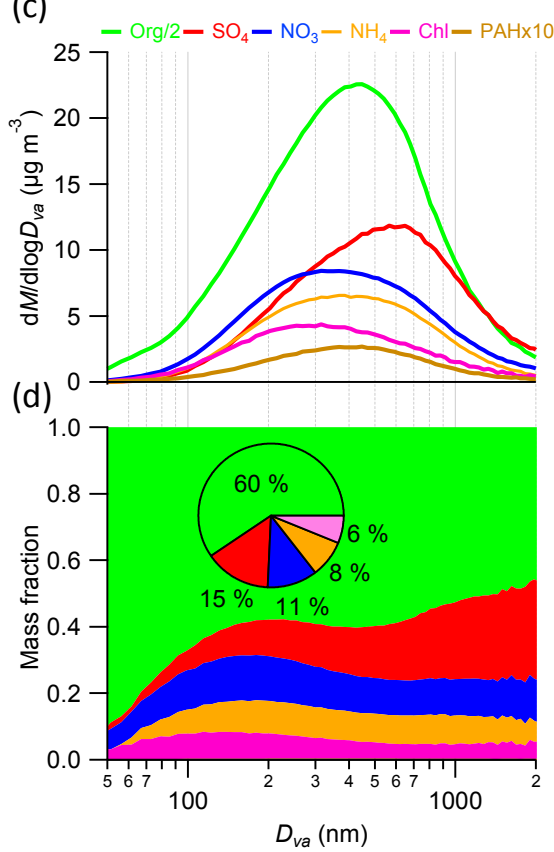

Figure 4. Average diurnal cycles of (a) NR-PM $\mathrm{PM}_{1}$ species and (b) NR-PM $\mathrm{P}_{1}$ species/ $\Delta \mathrm{CO}$, panels (c) and (d) show the average mass size

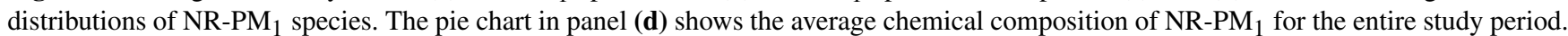

Zhang et al., 2014; Sun et al., 2015). High concentration of organics at night-time was also caused by intensive emissions from other primary sources, e.g. traffic and coal combustion (see Sect. 3.4 for more detail). The diurnal cycles of sulfate and nitrate were relatively similar, yet largely different from those observed during winter 2011-2012 (Sun et al., 2013b). These two species showed clear increases from $\sim 08: 00$, then decreased until late afternoon due to the elevated planetary boundary layer (PBL). Indeed, $\mathrm{SO}_{4} / \Delta \mathrm{CO}$ and $\mathrm{NO}_{3} / \Delta \mathrm{CO}$ after considering the dilution effect of PBL showed clear increases from 10:00 to 16:00 (Fig. 4b), indicating daytime photochemical production. Note that the daytime increase of $\mathrm{NO}_{3} / \Delta \mathrm{CO}\left(\sim 4 \mu \mathrm{g} \mathrm{m}^{-3} \mathrm{ppm}^{-1}\right)$ was nearly twice that of $\mathrm{SO}_{4} / \Delta \mathrm{CO}$, suggesting that photochemical processing was more important for nitrate than sulfate during this study. The primary species (e.g. chloride and PAHs) showed similar diurnal patterns which were both characterized by higher concentrations at night-time than daytime. Even considering the dilution effect of PBL, PAHs still showed higher concentrations at night, demonstrating the increased coal combustion emissions from residential heating.

The size distributions of NR-PM ${ }_{1}$ species in this study were largely different from those observed in summer (Huang et al., 2010; J. Sun et al., 2010; Hu et al., 2016), yet 

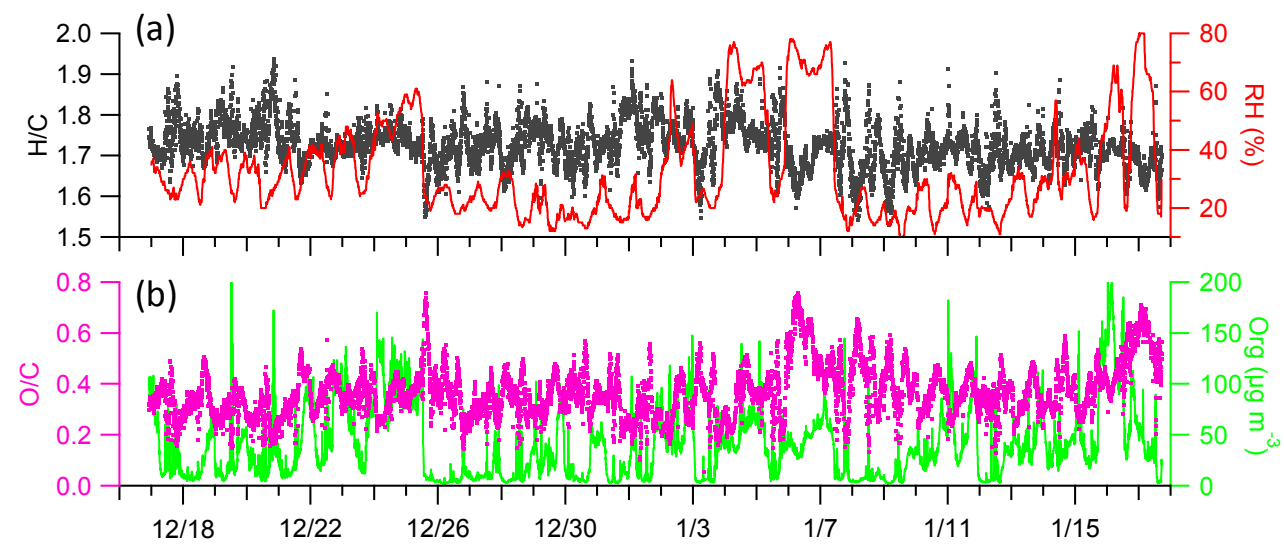

(c)

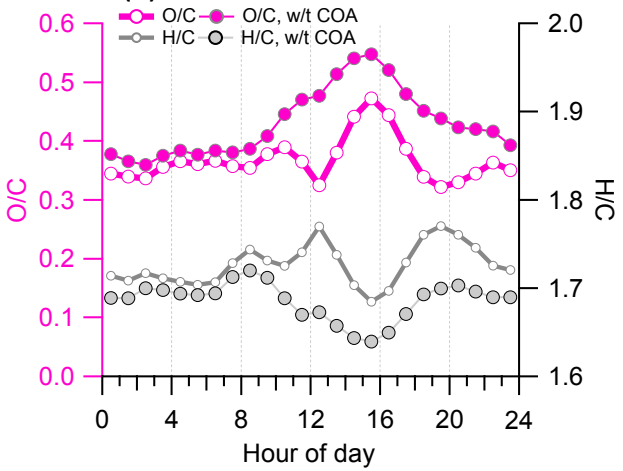

(d)

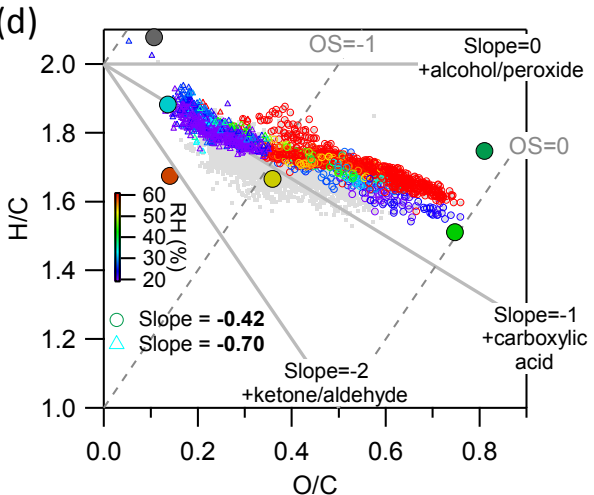

Figure 5. Time series of (a) $\mathrm{H} / \mathrm{C}$ and (b) $\mathrm{O} / \mathrm{C}$ ratios, (c) average diurnal cycles of $\mathrm{O} / \mathrm{C}$ and $\mathrm{H} / \mathrm{C}$. Also shown are the average diurnal cycles of elemental ratios by excluding the contribution of cooking organics aerosol and (d) Van Krevelen diagram of H/C vs. O/C. The RH colour-coded triangle and circle points represent the data with the contributions of aq-OOA and COA being larger than 20 and $40 \%$, respectively.

resembled those in winter (Hu et al., 2016). While all NR$\mathrm{PM}_{1}$ species showed similarly large accumulation modes peaking at $\sim 600 \mathrm{~nm}$ in summer (Huang et al., 2010; J. Sun et al., 2010), they varied differently in winter. Organics showed a broad size distribution peaking at $\sim 450 \mathrm{~nm}$. Organics dominated NR-PM ${ }_{1}$ at small sizes with a contribution as high as $90 \%$, indicating that a substantial fraction of ultrafine particles during wintertime was organics. Indeed, organic particles below $100 \mathrm{~nm}$ showed the best correlation with COA (Fig. S7), indicating a dominant contribution of cooking emissions on ultrafine particles. The contribution of organics decreased rapidly as a function of size, and larger organic particles (e.g. $>400 \mathrm{~nm}$ ) correlated much better with SOA and SIA (Fig. S7). These results indicate the different sources in organics at different size ranges. While small organic particles were mainly from primary emissions, those at large size ranges were primarily contributed to by secondary aerosols. The size distributions of nitrate and sulfate were quite different. While the two species shared similar size distributions in summer, they peaked at different sizes, at $\sim 600$ and $\sim 300-400 \mathrm{~nm}$, respectively. These results indicate that sulfate and nitrate were more likely externally mixed and have different formation mechanisms in winter. Indeed, although nitrate correlated well with sulfate $\left(r^{2}=0.81\right)$, the correlations and the ratios of $\mathrm{SO}_{4} / \mathrm{NO}_{3}$ were strongly $\mathrm{RH}$ dependent, indicating the different roles of aqueous-phase and photochemical processing in the formation of sulfate and nitrate. While nitrate showed comparable contributions across different size ranges $(\sim 10-15 \%)$, the sulfate contribution was significantly elevated at larger sizes with a contribution up to $30 \%$. PAHs showed a large single accumulation mode peaking at $\sim 400 \mathrm{~nm}$. The contribution of PAHs also peaked at similar size ranges indicating that coal combustion emissions appeared not to emit a large amount of small particles.

\subsection{Oxidation states of $\mathrm{OA}$}

Figure 5 shows the time series of $\mathrm{H} / \mathrm{C}$ and $\mathrm{O} / \mathrm{C}$ ratios during this study period. The $\mathrm{O} / \mathrm{C}$ varied substantially with hourly average, ranging from 0.18 to 0.71 . The average $\mathrm{O} / \mathrm{C}$ was $0.37 \pm 0.10(0.29 \pm 0.08$ with A-A method $)$, which was relatively low compared to those (0.32-0.41, A-A method) previously reported in Beijing (Huang et al., 2010; Zhang et al., 2014; Xu et al., 2015; Zhang et al., 2015). These results suggest that $\mathrm{OA}$ in this study was overall less oxidized. However, several periods with high $\mathrm{O} / \mathrm{C}$ ratios associated with 

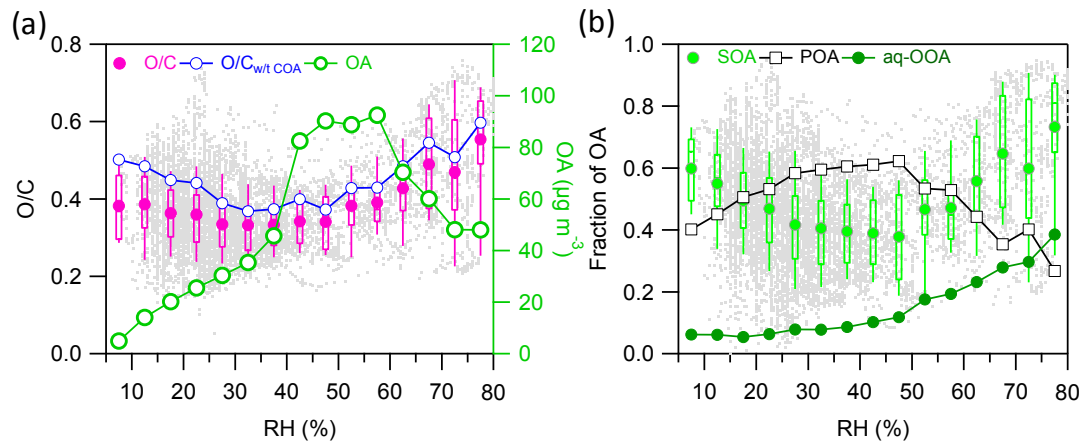

Figure 6. Variations of (a) $\mathrm{O} / \mathrm{C}$ and OA, (b) mass fractions of POA, SOA and aq-OOA as a function of RH. The data points are grouped in RH bins (5\% increment).

high RH, e.g. 6 and 17 January, were also observed, indicating very different oxidation degrees of OA. The OM / OC ratio was highly correlated with $\mathrm{O} / \mathrm{C}\left(r^{2}=0.998\right)$, with an average value of $1.64 \pm 0.13(1.53 \pm 0.11$ with $\mathrm{A}-\mathrm{A}$ method $)$. The OM / OC ratio is similar to the one suggested for the urban sites (Turpin and Lim, 2001). The O / C ratio showed a pronounced diurnal cycle with higher values during the daytime. Similar O / C diurnal cycles have been widely observed in various seasons in Beijing (Zhang et al., 2014, 2015; Hu et al., 2016). However, the daytime increase of $\mathrm{O} / \mathrm{C}$ was interrupted by a clear decrease at noon due to the influences of cooking emissions. In fact, the average $\mathrm{O} / \mathrm{C}$ ratio excluding the COA contribution showed a continuous increase from 0.38 at 08:00 to 0.55 at 16:00, and the $\mathrm{H} / \mathrm{C}$ ratio showed a corresponding decrease from 1.72 to 1.64 . Such a diurnal cycle demonstrated the photochemical processing in the daytime. The Van Krevelen plot showed that the relationship between $\mathrm{H} / \mathrm{C}$ and $\mathrm{O} / \mathrm{C}$ appeared to be quite different at different levels of oxidation. For example, the slope of $\mathrm{H} / \mathrm{C}$ vs. O / $\mathrm{C}$ was -0.70 during the period with the COA contribution larger than $40 \%$, which is much steeper than -0.42 during the period with high aq-OOA $(>20 \%)$. These results indicated the different evolutionary mechanisms between primary OA and highly oxidized OA (Chen et al., 2015).

Figure 6 a shows the variations of $\mathrm{O} / \mathrm{C}$ as a function of $\mathrm{RH}$. The $\mathrm{O} / \mathrm{C}$ first showed a slight decrease at $\mathrm{RH}<50 \%$, then had a rapid increase until $\mathrm{RH}=80 \%$. The $\mathrm{O} / \mathrm{C}$ ratio by excluding the influences of COA showed similar RH dependence. Higher O / C ratios at higher RH levels are likely to indicate the aqueous-phase processing in the formation of highly oxidized organic aerosols. By investigating the OA composition change as a function of $\mathrm{RH}$, we found that the POA contribution decreased from $\sim 60$ to $25 \%$ as the RH increased from 40 to $80 \%$; correspondingly, the SOA contribution increased from 40 to $70 \%$, and in particular aqOOA increased from 10 to $40 \%$. As a result, the increase of $\mathrm{O} / \mathrm{C}$ ratio at high $\mathrm{RH}$ levels was mainly caused by the increase of aq-OOA. As discussed in Sect. 3.4.5, aq-OOA in this study is likely to be an oxidized aqueous-phase pro- cessed OA. These results suggest that aqueous-phase processing can form highly oxidized SOA and also enhance oxidation degree of OA in winter (Ge et al., 2012b). This conclusion appeared to be different from a previous winter study in which $f_{44}$ (fraction of $m / z 44$ in OA), a surrogate of $\mathrm{O} / \mathrm{C}$, was relatively constant at high RH levels (Sun et al., 2013a). We noticed that the variations of mass concentrations of OA factors as a function of RH between the two studies. For example, most OA factors showed almost linear increases at low RH levels, reaching maxima at $\sim 50 \%$, then decreasing rapidly between 50 and $80 \%$ (Fig. S8). The aq-OOA concentration was low at $\mathrm{RH}<40 \%$, showed a large increase between 40 and $60 \%$, then remained relatively constant at high RH levels. Such a RH dependence of OA composition was significantly different from that observed during winter 2011-2012 when all OA factors remained at high concentrations at high RH levels (Sun et al., 2013a). Our results suggest that the OA sources and evolution processes at high $\mathrm{RH}$ levels might vary significantly in different years.

\subsection{Sources and variations of $\mathrm{OA}$}

Compared to our previous ACSM study during winter 20112012 (Sun et al., 2013b), PMF-HMR and PMF-UMR were able to identify six OA factors, including four POA factors (HOA, COA, BBOA and CCOA) and two SOA factors (OOA and aq-OOA). Although similar PMF resolution was obtained in winter 2010 and 2014 (Elser et al., 2016; Hu et al., 2016), we found that OA sources, variations and processes can vary substantially in different years.

\subsubsection{Hydrocarbon-like OA}

The HOA spectrum was characterized by typical hydrocarbon ion series of $\mathrm{C}_{n} \mathrm{H}_{2 n+1}^{+}$and $\mathrm{C}_{n} \mathrm{H}_{2 n+1}^{+}$(Fig. 7a), which is similar to those observed at various urban sites ( $\mathrm{Ng}$ et al., 2011) and from diesel exhausts (Canagaratna et al., 2004). Consistently, $\mathrm{HOA}$ was highly correlated with $\mathrm{C}_{n} \mathrm{H}_{2 n+1}^{+}$ ions, e.g. $\mathrm{C}_{3} \mathrm{H}_{7}^{+}, \mathrm{C}_{4} \mathrm{H}_{9}^{+}, \mathrm{C}_{5} \mathrm{H}_{11}^{+}, \mathrm{C}_{6} \mathrm{H}_{13}^{+}, \mathrm{C}_{7} \mathrm{H}_{15}^{+}$and $\mathrm{C}_{8} \mathrm{H}_{17}^{+}$ $\left(r^{2}>0.80\right.$, Fig. 8). The $\mathrm{O} / \mathrm{C}$ of HOA is 0.11 , which is lower 


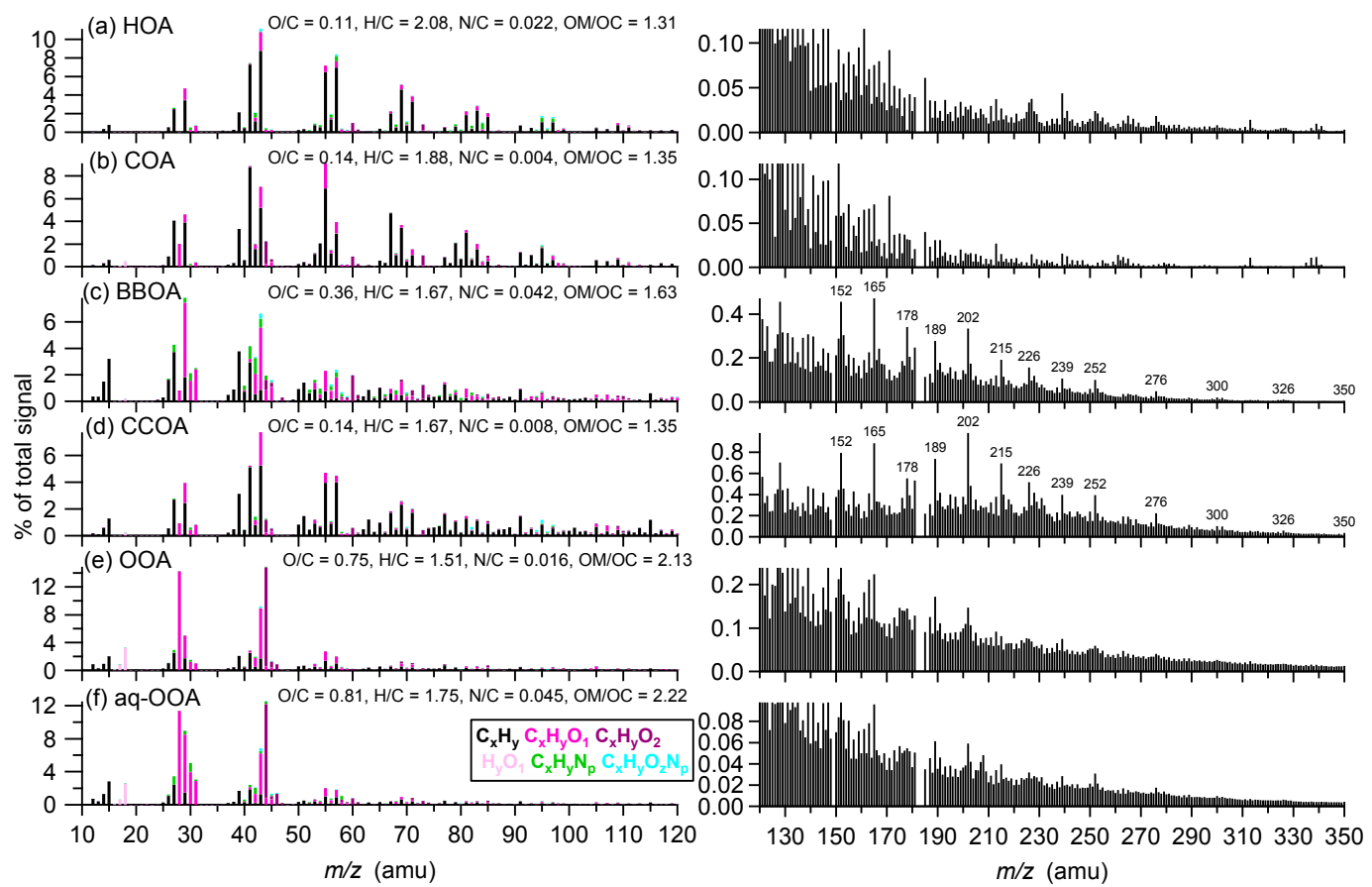

Figure 7. Left panel: high resolution mass spectra of six OA factors. Right panel: unit mass resolution spectra $(\mathrm{m} / z$ 120-350) of six OA factors.

than observed in summer (0.17) (Huang et al., 2010) and January 2013 (Zhang et al., 2014), indicating that HOA during this study period was primarily from fresh emissions. Indeed, HOA was tightly correlated with $\mathrm{NO}_{x}$ and $\mathrm{CO}\left(r^{2}=\right.$ 0.73 and 0.69 , respectively, Fig. S4), two tracers for vehicle emissions, yet presented much weaker correlations with secondary aerosol species $\left(r^{2}<0.3\right)$. The diurnal cycle of HOA was characterized by high concentration at night due to the enhanced traffic emissions from diesel trucks and heavy duty vehicles (Han et al., 2009), as well as shallow PBL at night. Such a diurnal cycle was similar to previously observed cycles in winter in Beijing (Sun et al., 2013b; Zhang et al., 2015; Hu et al., 2016). HOA on average accounted for $10 \%$ $(6-14 \%)$ of the total OA for the entire study period, which is much lower than the $18 \%$ during the Beijing 2008 Olympic Games (Huang et al., 2010), yet close to the $11 \%$ reported in January 2013 (Zhang et al., 2014) and $14 \%$ in winter 2010 (Hu et al., 2016).

\subsubsection{Cooking OA}

Similar to previously reported COA, the mass spectrum was characterized by high $m / z$ 55/57 ratio (He et al., 2010; Sun et al., 2011; Mohr et al., 2012). COA contributed 31 and $36 \%$ to $\mathrm{C}_{3} \mathrm{H}_{3} \mathrm{O}^{+}$and $\mathrm{C}_{4} \mathrm{H}_{7}^{+}$, respectively, at $\mathrm{m} / z$. 55 and $\sim 21 \%$ to $\mathrm{C}_{3} \mathrm{H}_{5} \mathrm{O}^{+}$and $\mathrm{C}_{4} \mathrm{H}_{9}^{+}$at $m / z$ 57. Although $m / z 55$ is often used as a tracer for cooking emissions, our results indicated that $\mathrm{COA}$ correlated much better with several other fragment ions, e.g. $\mathrm{C}_{6} \mathrm{H}_{10} \mathrm{O}^{+}, \mathrm{C}_{5} \mathrm{H}_{8} \mathrm{O}^{+}, \mathrm{C}_{4} \mathrm{H}_{6}^{+}$,

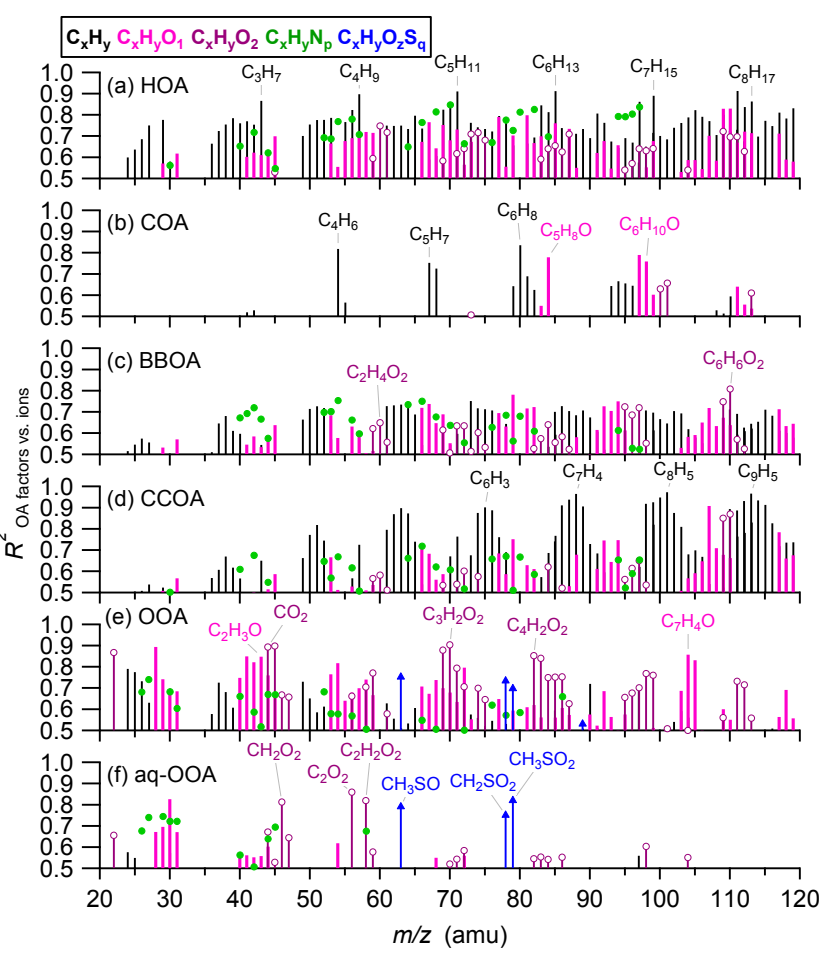

Figure 8. Correlations between six OA factors and HRMS ions that are segregated into five categories $\left(\mathrm{C}_{x} \mathrm{H}_{y}^{+}, \mathrm{C}_{x} \mathrm{H}_{y} \mathrm{O}^{+}, \mathrm{C}_{x} \mathrm{H}_{y} \mathrm{O}_{2}^{+}\right.$, $\mathrm{C}_{x} \mathrm{H}_{y} \mathrm{~N}_{p}^{+}$and $\mathrm{C}_{x} \mathrm{H}_{y} \mathrm{O}_{z} \mathrm{~S}_{q}^{+}$). 
$\mathrm{C}_{5} \mathrm{H}_{7}^{+}$and $\mathrm{C}_{6} \mathrm{H}_{8}^{+}$(Fig. 8). Compared to the results in New York City, $\mathrm{COA}$ showed similarly tight correlations with $\mathrm{C}_{6} \mathrm{H}_{10} \mathrm{O}^{+}$and $\mathrm{C}_{5} \mathrm{H}_{8} \mathrm{O}^{+}$, yet much weaker correlations with large hydrocarbon ions (Sun et al., 2011). These results suggest that $\mathrm{C}_{6} \mathrm{H}_{10} \mathrm{O}^{+}$and $\mathrm{C}_{5} \mathrm{H}_{8} \mathrm{O}^{+}$are better tracers for cooking emissions than the unit $\mathrm{m} / z 55$ and 57 although they contribute small fractions to the total organics. The ratio of $\mathrm{COA} / \mathrm{C}_{6} \mathrm{H}_{10} \mathrm{O}^{+}$is 184 , which is close to that obtained in winter in Fresno, California (Ge et al., 2012a) and New York City (Sun et al., 2011) (170 and $\sim 180$, respectively). As a result, the $\mathrm{COA}$ aerosol could be simply estimated with the equation of $\mathrm{COA}=180 \times \mathrm{C}_{6} \mathrm{H}_{10} \mathrm{O}^{+}$. The $\mathrm{O} / \mathrm{C}$ of $\mathrm{COA}$ is 0.14 which is similar to those observed in winter in Beijing and Fresno, CA (Ge et al., 2012a; Zhang et al., 2014; Hu et al., 2016), and fresh cooking emissions (0.08-0.13) (He et al., 2010). These results indicate that COA is mainly composed of low oxygenated organics. In addition, COA showed much better correlation with smaller organic particles, e.g. $<100 \mathrm{~nm}$ (Fig. S7), indicating substantial emissions of ultrafine particles from cooking activities.

COA showed a pronounced diurnal cycle with two prominent peaks at lunch and dinner time and a visible morning breakfast peak at $\sim 08: 00$. Such a unique diurnal cycle of COA has been observed many times in megacities. COA on average accounted for $18 \%$ of the total OA with the highest contribution close to $40 \%$ during meal times. COA has been found to show comparable and even higher contributions than traffic-related HOA in densely populated megacities, e.g. New York City (16 vs. 14\%) (Sun et al., 2011), Paris (15-17 vs. 11-14.3\%) (Crippa et al., 2013; Fröhlich et al., 2015), London (22-30 vs. 23-25\%) (Allan et al., 2010), Fresno (19 vs. $22 \%$ ) (Ge et al., 2012a) and Beijing (24 vs. 18\%) (Huang et al., 2010). A recent study found that emissions from residential heating and cooking have the largest impact on premature mortality globally (Lelieveld et al., 2015). Particularly, aerosol particles tend to be present at small size ranges during the periods with high COA contribution, which are subject to more adverse health effects. Therefore, reducing cooking emissions is of importance, not only in mitigating urban PM pollution, but also alleviating the harmful effects in densely populated megacities.

\subsubsection{Coal combustion OA}

CCOA showed a similar spectral pattern to HOA at small $m / z$ 's $(<120)$ (Fig. 7d). The largest difference is $m / z 115$ (mainly $\mathrm{C}_{9} \mathrm{H}_{7}^{+}$) which is prominent in the CCOA spectrum yet much smaller in HOA spectrum. The CCOA spectrum showed a visible $m / z 44$ peak, yet it is much smaller than those observed in Beijing (Hu et al., 2016) and Lanzhou (Xu et al., 2016). The spectral differences were likely due to different burning conditions and ageing processes. For example, a recent study by burning different types of coals showed that the CCOA spectrum, particularly $m / z 44$ and 73 , can have significant changes during the different stages of the burning, and high $m / z 44$ in the spectrum was mainly the fragments of organic acids (Zhou et al., 2016). Although CCOA was separated from HOA by PMF analysis of ACSM UMR spectra in our previous study during winter 2011-2012 (Sun et al., 2013b), the interpretation of these two components were quite difficult due to the absence of the information at large $m / z$ 's (> 150). In this study, PMF analysis of UMR spectra to $\mathrm{m} / \mathrm{z} 350$ showed strong PAH signatures in the CCOA spectrum, which are $m / z$ 's $152,165,178,189,202,215,226$, $239,252,276,300,326$ and 350 (Dzepina et al., 2007). The distinct PAH peaks of $m / z$ 's $152,165,178$ and 189 were already observed in the CCOA spectrum resolved in Beijing in winter 2010 (Hu et al., 2016) and a rural site in central China (Hu et al., 2013). Comparatively, the traffic-related HOA did not present pronounced PAH signals, which was different from those observed at morning rush hours in Mexico City (Dzepina et al., 2007). This likely indicates that a dominant source of PAHs is coal combustion. In fact, CCOA was highly correlated with PAHs $\left(r^{2}=0.92\right.$, Fig. 8d). In addition, CCOA was found to have ubiquitously tight correlations with large $m / z$ 's (>150) (Fig. S9), and contributed more than $40 \%$ for most $m / z$ 's (Fig. S10). This likely indicates that coal combustion emits a considerable amount of high molecular weight organics. The $\mathrm{O} / \mathrm{C}$ of CCOA is 0.14 suggesting that organic aerosols emitted from coal combustion are fresh. Higher O / C ratio of CCOA (0.17) observed at the rural site (Hu et al., 2013) was likely due to the atmospheric ageing during the transport.

The average mass concentration of CCOA was $7.6 \mu \mathrm{g} \mathrm{m}^{-3}$, which is lower than $\left(11.3 \mu \mathrm{g} \mathrm{m}^{-3}\right)$ observed during winter 2011-2012 (Sun et al., 2013b), yet similar to those (7.3$8.2 \mu \mathrm{g} \mathrm{m}^{-3}$ ) in January 2013 and winter 2010 (Sun et al., 2014; Hu et al., 2016). CCOA was the largest primary OA, on average accounting for $20 \%$. CCOA showed a pronounced diurnal cycle with significantly higher concentration at nighttime than daytime (Fig. 8g). The contribution of CCOA to OA reached $37 \%$ at night-time, which is much higher than $7 \%$ during the daytime. After considering the PBL dilution effect, CCOA still showed a pronounced diurnal variation, illustrating much stronger coal combustion emissions at night.

\subsubsection{Biomass burning OA}

Compared to previous AMS winter studies in Beijing (Sun et al., 2013b, 2014; Zhang et al., 2014, 2015), we were able to resolve a factor, the mass spectrum of which was characterized by prominent $\mathrm{m} / \mathrm{z} 60$ (mainly $\mathrm{C}_{2} \mathrm{H}_{4} \mathrm{O}_{2}^{+}$) and 73 $\left(\mathrm{C}_{3} \mathrm{H}_{5} \mathrm{O}_{2}^{+}\right)$, two markers indicative of biomass burning emissions (Lanz et al., 2007; Mohr et al., 2009). The two recent AMS studies also resolved BBOA factors in winter in Beijing (Elser et al., 2016; Hu et al., 2016). Consistently, the BBOA spectrum resembles to those observed at various sites $(\mathrm{Ng}$ et al., 2011), e.g. Fresno, CA (Ge et al., 2012a) and Mexico City (Aiken et al., 2009). Although BBOA was tightly correlated with $\mathrm{C}_{2} \mathrm{H}_{4} \mathrm{O}_{2}^{+}\left(r^{2}=0.65\right)$, similar high correla- 
tions between $\mathrm{C}_{2} \mathrm{H}_{4} \mathrm{O}_{2}^{+}$and primary $\mathrm{HOA}$ and CCOA were also observed, indicating the contributions of multiple combustion sources to $m / z 60$ (Fig. 8). Indeed, the four primary OA factors showed comparable contributions to ion $\mathrm{C}_{2} \mathrm{H}_{4} \mathrm{O}_{2}^{+}$ in this study. We noticed that BBOA showed the best correlation with $\mathrm{C}_{6} \mathrm{H}_{6} \mathrm{O}_{2}^{+}(\mathrm{m} / z$ 110), a marker ion for hydroquinone and catechol from the pyrolysis of lignin and/or the hydroxylation of phenol (Y. L. Sun et al., 2010), supporting the influence of biomass burning emissions on this factor. In addition, similar strong PAHs signals to CCOA were also observed at large $m / z$ 's, suggesting that BBOA is also an important source of PAHs during wintertime. BBOA showed a similar diurnal pattern to CCOA which was characterized by high concentration at night-time. The $\mathrm{O} / \mathrm{C}$ ratio of $\mathrm{BBOA}$ is 0.36 , which is similar to those observed at other urban sites (Aiken et al., 2009; He et al., 2011; Huang et al., 2011; Ge et al., 2012a). It's interesting to note that BBOA presents a high $\mathrm{N} / \mathrm{C}$ ratio $(=0.042)$ compared to the other three primary factors, which is likely due to the large amount of nitrogencontaining organic compounds emitted from biomass burning emissions (Laskin et al., 2009). Consistently, high N / C ratios in BBOA $(\sim 0.06)$ were also observed in Pearl River delta (He et al., 2011; Huang et al., 2011). The average mass concentration of BBOA was $3.3 \mu \mathrm{g} \mathrm{m}^{-3}$ ( $9 \%$ of the total $\mathrm{OA}$ ), indicating that BBOA is an important source of OA during wintertime. The overall concentration and contribution of BBOA was consistent with the values previously reported in Beijing in winter (Elser et al., 2016; Hu et al., 2016).

BBOA was highly correlated with levoglucosan $\left(r^{2}=\right.$ 0.93, Fig. 10a), a common tracer compound for biomass burning (Simoneit, 2002). The average ratio of levoglucosan to organic carbon $(\mathrm{OC})$ derived from BBOA is 0.257 , which is generally higher than from burning individual biomass (Sullivan et al., 2008) and during the BB episode in summer in Beijing (0.036) (Cheng et al., 2013). Previous studies showed that coal combustion also emits a considerable amount of levoglucosan (Zhang et al., 2008). In fact, levoglucosan was also correlated with the total OC from BBOA and CCOA $\left(r^{2}=0.91\right)$, yielding an average ratio of levoglucosan / OC of 0.062 . The ratio of levoglucosan/mannosan $(L / M)$ can be used to indicate different types of burning. For example, burning hardwood showed a much higher $L / M$ ratio compared to burning softwood. Cheng et al. (2013) observed quite different $L / M$ ratios for different types of biomass burning, e.g. 12.7 for wheat straw and 19.7 for corn straw, yet much lower values for pine and poplar wood. In this study, levoglucosan was highly correlated with mannosan (Fig. 10b, $r^{2}=0.95$ ), and the ratio of $L / M(17.1)$ is similar to those from burning wheat straw and corn straw (Cheng et al., 2013). We also noticed that the $L / M$ ratio in this study is similar to those (14.8-19.6) from residential burning of bituminite and coal briquette (Zhang et al., 2008), likely indicating the contribution of coal combustion to these two compounds. This is further supported by the visible $m / z 60$ in the CCOA spectrum. As a result, levoglucosan and mannosan observed in this study were likely from both biomass burning and coal combustion; however it is difficult to separate them only based on $L / M$ ratios. We further calculated the bivariate polar plot of BBOA (Fig. S11) and found that a high concentration of BBOA was mainly located in the regions to the north and north-east, and likely has mixed sources from local emissions and regional transport.

\subsubsection{Secondary organic aerosols}

Two SOA factors, i.e. OOA and aq-OOA, with similar spectral patterns yet largely different time variations, were identified. While the $\mathrm{O} / \mathrm{C}$ ratios were similar between OOA and aq-OOA ( 0.75 vs. 0.81$)$, the $\mathrm{H} / \mathrm{C}$ ratio was much more different (1.51 for OOA and 1.75 for aq-OOA). We also noticed the different ratios of $\mathrm{C}_{2} \mathrm{H}_{3} \mathrm{O}^{+} / \mathrm{CO}_{2}^{+}$and $\mathrm{CHO}^{+} / \mathrm{CO}_{2}^{+}$in OOA and aq-OOA spectra. Indeed, the correlations between OOA/aq-OOA and individual fragment ions were quite different. As shown in Fig. 8, OOA was highly correlated with the oxygenated ion series $\mathrm{C}_{x} \mathrm{H}_{y} \mathrm{O}_{2}^{+}$and $\mathrm{C}_{x} \mathrm{H}_{y} \mathrm{O}_{1}^{+}$, e.g. $\mathrm{CO}_{2}^{+}$ $\left(m / z 44, r^{2}=0.89\right), \mathrm{C}_{2} \mathrm{H}_{3} \mathrm{O}^{+}\left(m / z 43, r^{2}=0.85\right), \mathrm{C}_{3} \mathrm{H}_{2} \mathrm{O}_{2}^{+}$ $\left(m / z 70, r^{2}=0.90\right)$ and $\mathrm{C}_{4} \mathrm{H}_{2} \mathrm{O}_{2}^{+}\left(m / z 82, r^{2}=0.85\right)$ etc., yet the correlations with hydrocarbon ions $\mathrm{C}_{x} \mathrm{H}_{y}^{+}$were much weaker. These results indicate that OOA was primarily composed of oxygenated organics. OOA was tightly correlated with $\mathrm{O}_{x}\left(r^{2}=0.73\right)$ and $\mathrm{NO}_{3}\left(r^{2}=0.71\right)$, consistent with previous results observed in January 2013 (Sun et al., 2014). The diurnal cycle of OOA was significant, showing an increase from 08:00 to 20:00. The daytime increase was interrupted by a temporary decrease in the afternoon due to the dilution effect of PBL. In fact, OOA / $\triangle \mathrm{CO}$ presented a continuous increase from 08:00 to 14:00, then remained at a relatively high level until 19:00 (Fig. S12). These results clearly indicate the photochemical production of OOA in the daytime. Based on the variations of OOA between 08:00 and 14:00, we estimated that local photochemical production could contribute $\sim 70 \%$ of OOA during this study. OOA on average contributed $25 \%$ of the total OA with the contribution as high as $42 \%$ in the late afternoon.

The aq-OOA was highly correlated with specific unique fragment ions from typical aqueous-phase processing products. For example, aq-OOA correlated well with $\mathrm{C}_{2} \mathrm{H}_{2} \mathrm{O}_{2}^{+}$ $\left(m / z\right.$ 58), $\mathrm{C}_{2} \mathrm{O}_{2}^{+}\left(m / z\right.$ 56) and $\mathrm{CH}_{2} \mathrm{O}_{2}^{+}(m / z$ 46) (Fig. 8). These ions are typical fragment ions of glyoxal and methylgloxyal (Chhabra et al., 2010), which are important precursors in the formation of low volatility SOA in cloud processing (Carlton et al., 2007; Altieri et al., 2008; Tan et al., 2009). In addition, aq-OOA was also highly correlated with several sulfur-containing ions, e.g. $\mathrm{CH}_{3} \mathrm{SO}^{+}, \mathrm{CH}_{2} \mathrm{SO}_{2}^{+}$ and $\mathrm{CH}_{3} \mathrm{SO}_{2}^{+}$(Fig. 8), which are typical fragment ions of methanesulfonic acid (MSA), a secondary product from the oxidation of dimethyl sulfide (DMS) (Zorn et al., 2008; Ge et al., 2012b). Previous studies have found that hydromethanesulfonate (HMS) can be used a tracer for aqueous-phase fog processing. Although the HMS spectrum does not present 

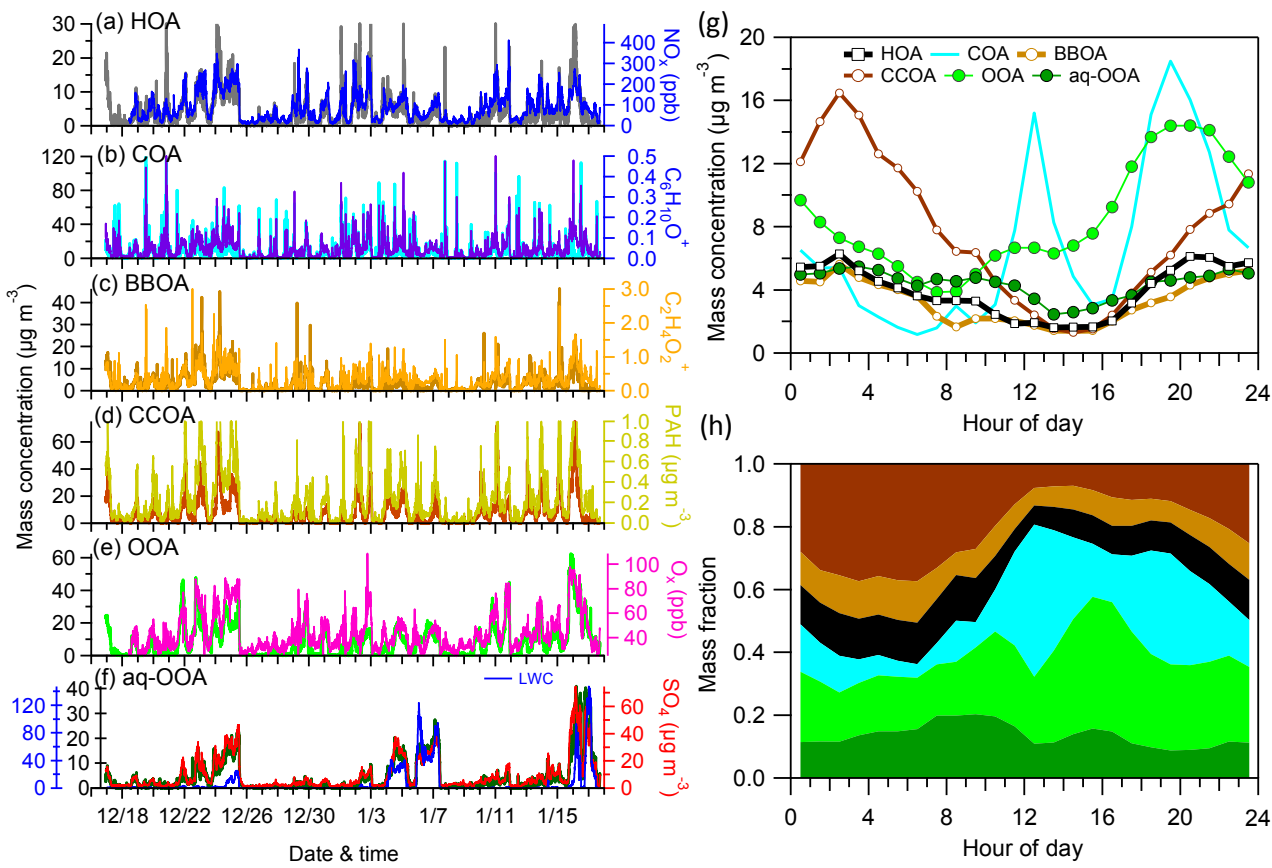

Figure 9. Time series of six OA factors and average diurnal cycles of mass concentrations and mass fractions of OA factors. The external tracer species, including $\mathrm{NO}_{x}, \mathrm{C}_{6} \mathrm{H}_{10} \mathrm{O}^{+}, \mathrm{C}_{2} \mathrm{H}_{4} \mathrm{O}_{2}^{+}$, $\mathrm{PAH}, \mathrm{O}_{x}$ and $\mathrm{SO}_{4}$, are also shown for comparison.

$\mathrm{CH}_{2} \mathrm{SO}_{2}^{+}$and $\mathrm{CH}_{3} \mathrm{SO}_{2}^{+}$peaks, it is unique in the absence of $\mathrm{SO}_{3}^{+} / \mathrm{HSO}_{3}^{+}$and $\mathrm{H}_{2} \mathrm{SO}_{4}^{+}$compared to pure ammonium sulfate (Ge et al., 2012b). Therefore, an elevated $\mathrm{SO}_{2}^{+} / \mathrm{SO}_{3}^{+}$ ratio would be expected if there is a considerable aqueousphase formation of HMS. In this study, we did observe a clear increase of the $\mathrm{SO}_{2}^{+} / \mathrm{SO}_{3}^{+}$ratio as a function of $\mathrm{RH}$ (Fig. S13) while the $\mathrm{SO}^{+} / \mathrm{SO}_{2}^{+}$ratio remained relatively constant $(\sim 0.69)$ across different RH levels. This result indicates the importance of aqueous-phase processing in this study. In addition, a high $\mathrm{N} / \mathrm{C}$ ratio (0.045) was also observed for aq-OOA, which is consistent with recent findings that aqueous-phase processing of glyoxal/methylglyoxal with amino acids and amines can form nitrogen-containing compounds (De Haan et al., 2009, 2010; Ge et al., 2011).

The time series of aq-OOA was largely different from other OA factors. The variations of aq-OOA tracked well with RH. As shown in Fig. 9f, aq-OOA showed high concentrations at high RH levels ( $>40 \%)$, while it remained at low levels at $\mathrm{RH}<40 \%$. The contribution of aq-OOA to OA showed a strong RH dependence. While it contributed less than $10 \%$ to $\mathrm{OA}$ at $\mathrm{RH}<40 \%$, the contribution rapidly increased as a function of $\mathrm{RH}$, and reached $44 \%$ at $\mathrm{RH}=80 \%$ (Fig. S8b). We further compared the time series of aq-OOA with aerosol liquid water content (LWC, Fig. 9f). It is clear that the periods with high LWC were characterized by high aq-OOA. These results support aq-OOA as a secondary factor that was strongly associated with aqueous-phase processing. Further support comes from the tight correlation be-
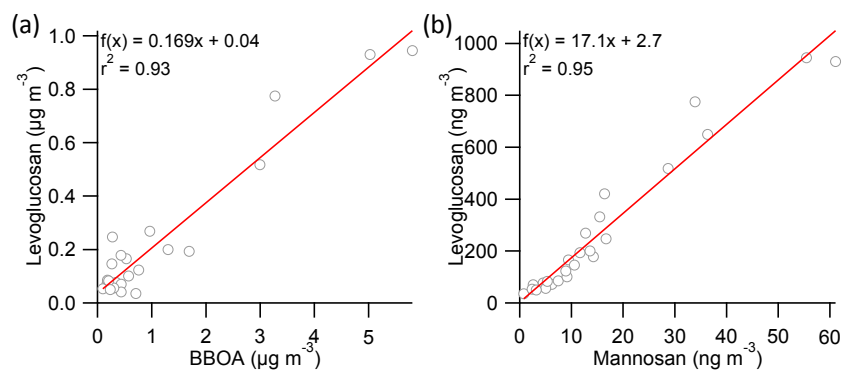

Figure 10. Correlations between levoglucosan and (a) BBOA and (b) Mannosan.

tween aq-OOA and sulfate $\left(r^{2}=0.93\right)$, a species primarily from aqueous-phase/cloud processing. We also noticed a relatively high concentration of aq-OOA during some periods with low RH and LWC. Considering that aq-OOA showed relatively flat diurnal variations, these results might indicate that aq-OOA is also likely from regional transport, during which it was well processed either via photochemical processing or aqueous-phase processing.

The SOA (=OOA + aq-OOA) on average accounted for $44 \%$ of OA, which is higher than $(31 \%)$ reported during wintertime 2011-2012 (Sun et al., 2013b), yet lower than (54-55\%) observed in January 2013 with severe PM pollution (Sun et al., 2014; Zhang et al., 2014). OOA and aqOOA on average contributed 32 and $12 \%$ to OA, respectively, which indicated that photochemical production was 
the major process in the formation of SOA during this study period.

\subsection{Polycyclic aromatic hydrocarbons (PAHs)}

PAHs mainly from incomplete combustion are of great concerns in megacities due to their carcinogenicity and mutagenicity (Boström et al., 2002). Knowledge of their concentration levels and sources is thus important for mitigation strategies of air pollution. Here we quantified the PAHs with AMS using the algorithm developed by Dzepina et al. (2007). The average concentration of PAHs is 0.22 $( \pm 0.27) \mu \mathrm{g} \mathrm{m}^{-3}$ for the entire study. The concentration is significantly higher than that $\left(21-29 \mathrm{ng} \mathrm{m}^{-3}\right)$ reported in summer in Lanzhou (Xu et al., 2014) and in autumn in Beijing (Zhang et al., 2016), yet close to that observed in the heating season (Okuda et al., 2006). These results illustrate the largely different sources of PAHs between the heating season and non-heating season. In this study, PAHs presented a pronounced diurnal cycle with a significantly higher concentration at night-time than in the daytime. Such a strong diurnal variation is remarkably similar to that of CCOA, confirming that coal combustion is a large source of PAHs during wintertime (Zhang et al., 2008). Indeed, the mass spectrum of CCOA showed distinct fragment $\mathrm{m} / \mathrm{z}$ 's from PAHs, e.g. $m / z 152,165,178,189,202,215,226,239,252,276,300$, 326, etc. (Fig. 7d). Note that the mass spectrum of BBOA (Fig. 7c) was also characterized by similar PAHs $m / z$ 's, suggesting that BBOA might also be a considerable contribution. For example, PAHs were highly correlated with BBOA in Fresno, California, yet the correlations with COA and HOA were much weaker. Similar tight correlations between BBOA and PAHs were also observed during the APEC summit in Beijing (Zhang et al., 2016). For a better understanding of the sources of PAHs, a linear regression analysis of OA factors was performed on PAHs.

$$
\begin{aligned}
{[\mathrm{PAHs}] } & =a_{\mathrm{CCOA}} \times[\mathrm{CCOA}]+a_{\mathrm{BBOA}} \times[\mathrm{BBOA}]+a_{\mathrm{HOA}} \\
& \times[\mathrm{HOA}]+a_{\mathrm{COA}} \times[\mathrm{COA}]+a_{\mathrm{other}} \times[\text { other }]
\end{aligned}
$$

The average contributions of OA sources to PAHs are shown in Fig. 11a. Coal combustion is the dominant source of PAHs, on average accounting for $66 \%$. This is consistent with the results from previous studies that coal combustion emits a large amount of PAHs (Chen et al., 2005; Zhang et al., 2008). Biomass burning and traffic emissions contributed 18 and $11 \%$, respectively, to the total PAHs. Cooking emissions were a minor source of PAH in this study, on average accounting for $3 \%$, which is also consistent with the fact that the amount of PAHs emitted from the Chinese cooking was small (Zhao et al., 2006).

Figure $11 \mathrm{~b}$ shows a comparison of OA spectra during a haze episode on 24 December with that during rush traffic hours in Mexico City (Dzepina et al., 2007). While the spectra were both characterized by distinct PAH signals, the PAH spectra patterns were quite different, indicating that the composition of PAHs was substantially different between coal combustion and traffic emissions. We further compared the OA spectra at two different night-time periods and the spectra pattern $(m / z>150)$ was remarkably similar $\left(r^{2}=0.99\right.$, Fig. 11d), suggesting similar source emissions on different days. However, the average OA spectra in the afternoon showed differences from those at night-time, likely indicating that photochemical processing changed OA composition to a certain degree. The average size distribution of PAHs showed a large single mode peaking at $\sim 400 \mathrm{~nm}$, which is similar to observations in Mexico City (Dzepina et al., 2007). The size distributions of PAHs were quite similar between different episodes which were both characterized by single accumulation modes peaking at $\sim 400-500 \mathrm{~nm}$.

\subsection{Episode analysis}

Many previous studies have found largely different aerosol composition between clean periods and haze episodes in Beijing (Huang et al., 2010; Sun et al., 2012, 2013b; Jiang et al., 2015). In this study, we also observed frequent changes of clean periods and pollution episodes (Fig. 1). Five episodes (E1-E5) with relatively high RH levels (>50\%), five episodes (M1-M5) with RH levels between 20 and $40 \%$, and two clean periods $(\mathrm{C} 1-\mathrm{C} 2)$ were selected to investigate the variations of aerosol chemistry among different episodes. The average mass concentrations of NR-PM 1 varied substantially from 105 to $255 \mu \mathrm{g} \mathrm{m}^{-3}$ during E1-E5, which was generally higher than those $\left(67-158 \mu \mathrm{g} \mathrm{m}^{-3}\right)$ during M1-M5. The average composition was also different. While the contribution of organics varied between 40 and $58 \%$ during E1E5, it was relatively constant at $62-67 \%$ during M1-M5, indicating a more important role of organics in PM pollution at lower RH levels. Sulfate also played a very different role during the two types of episodes with a much higher contribution (17-24\%) during E1-E5 than the 8-13\% during M1-M5. This result is consistent with our previous conclusion that sulfate played an enhanced role at high RH levels due to aqueous-phase processing. OA composition varied greatly among different episodes. But overall, episodes with high RH levels showed much higher aq-OOA contributions than those in episodes with low RH levels. Because the average temperature and wind speed were relatively similar, such compositional differences were mainly caused by different RH conditions. For instance, two episodes, i.e. E3 and E5, showed much higher SOA contributions $(67-77 \%)$ than the other episodes (22-49\%). The two episodes of E3 and E5 were characterized by the highest RH and aq-OOA (37$45 \%$ ), likely indicating strong aqueous-phase processing of $\mathrm{OA}$. The $\mathrm{O} / \mathrm{C}$ ratios during the two episodes were also the highest (0.56-0.60), demonstrating that aqueous-phase processing enhanced the oxidation levels of OA. CCOA was the largest primary OA for most episodes with the contributions ranging from 22 to $31 \%$ except for E3 and E5. Sev- 


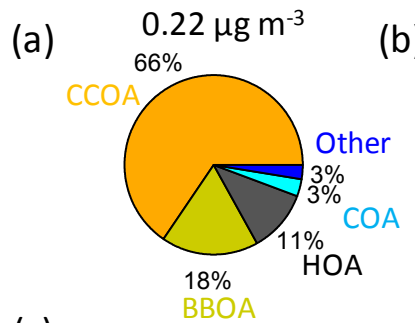

(c)

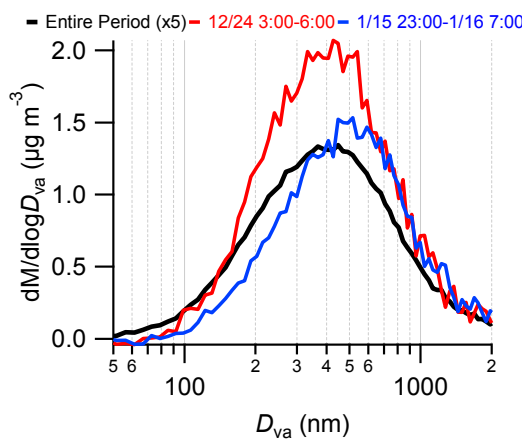

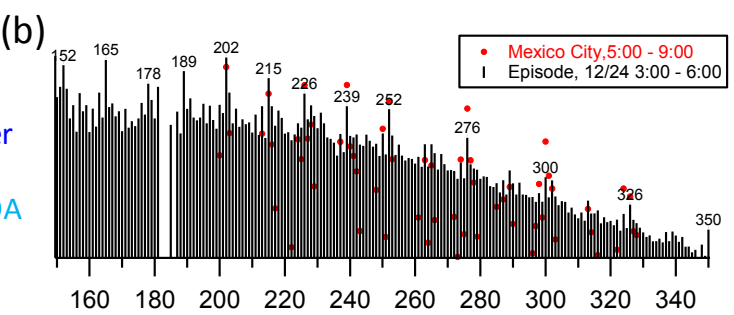

(d)

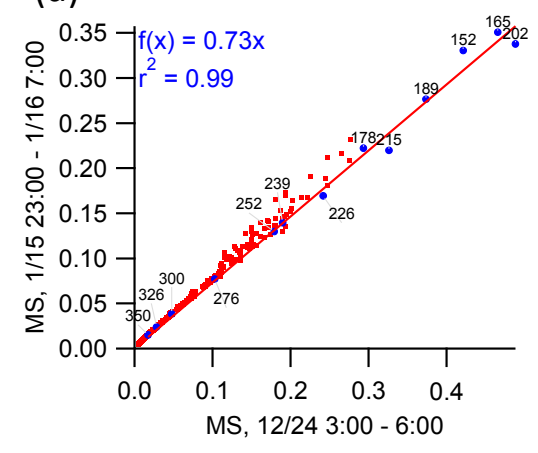

Figure 11. (a) Average contributions of OA factors to PAHs for the entire study, (b) UMR OA spectra during an episode (03:00-06:00 on 24 December). The average PAH spectrum between 05:00 and 09:00 h in Mexico City (Dzepina et al., 2007) is shown for comparison. Panel (c) shows the average size distribution of PAHs for the entire study and two selected episodes and panel (d) presents a comparison of OA spectra $(m / z, 150-300)$ between the two episodes.

eral episodes (M3 and C1-C2) with significant local cooking influences (COA: 27-45\%) were also observed. In addition to the RH impacts, the sources emissions were also likely to be different among different episodes. The $\mathrm{CO} / \mathrm{NO}_{x}$ ratios varied from 23 to 40 during E1-E5, while they were generally low-ranging from 15 to 22 during M1-M5. Also, the $\mathrm{NO}_{2} / \mathrm{NO}_{x}$ ratios were generally higher $(0.40-0.59)$ during E1-E5 than $0.33-0.45$ during M1-M5, and even higher (0.67-0.69) during C1-C2. The size distributions of aerosol species are also substantially different between the two types of episodes. The episodes with high RH levels (E1-E5) showed larger maximum diameters than those during M1M5, for instance, $>500$ vs. $300-500 \mathrm{~nm}$ for sulfate and 400 700 vs. $200-400 \mathrm{~nm}$ for nitrate. In contrast, the differences in size distributions of organics and PAHs were much smaller (Fig. 12b and c). Larger particles of sulfate and nitrate were likely due to the hygroscopic growth at high RH levels.

Figure 13 shows the evolution of secondary aerosol species and size distributions over two periods with different RH levels. The first period contains two episodes, i.e. M1 and M2 in Fig. 1. The formation of M1 was clearly associated with a change of air masses from the north to the south-west that occurred at approximately 12:00 on 21 December. Winds remained consistently from the south-west over the next $10 \mathrm{~h}$ and $\mathrm{RH}$ increased gradually from $\sim 20$ to $40 \%$. Under such meteorological conditions, nitrate and sulfate showed gradual increases from less than $5 \mu \mathrm{g} \mathrm{m}^{-3}$ to more than $20 \mu \mathrm{g} \mathrm{m}^{-3}$. The mean geometric diameters (GMD) showed similar increases, approximately from 180 to $450 \mathrm{~nm}$ for nitrate, and 270 to $570 \mathrm{~nm}$ for sulfate. However, we observed different evolution behaviours between OOA and aqOOA. While OOA showed similar increases to sulfate and nitrate, aq-OOA remained at relatively low concentrations. This indicates a dominance of OOA over aq-OOA during the early stage of regional transport with low RH levels. The episode of M1 was rapidly cleaned by the northerly winds until 12:00 on 22 December when wind direction changed to the south-south-west and the episode of M2 was formed. It is interesting to note that the wind direction changes did not result in immediate increases of all secondary aerosol species. In fact, wind speed firstly decreased at both ground level and higher altitudes (e.g. $320 \mathrm{~m}$ ), associated with corresponding decreases of RH. Nitrate and OOA showed clear increases during this stage, while the sulfate and aq-OOA concentrations were consistently low. One explanation is that secondary aerosols during the early stage of these two episodes were mainly from local photochemical production, consistent with the increasing $\mathrm{O} / \mathrm{C}$ ratios. After wind speed increased significantly at higher altitudes, relatively more humidified air masses from the south-south-west arrived at the sampling site, leading to dramatic increases of all secondary aerosol species.

The formation of episode E4 was more rapid compared to M1 (Fig. 13b). The mass concentrations of secondary sulfate, nitrate and OOA showed dramatic increases by a factor of $2-5$ in $1 \mathrm{~h}$ (17:00-18:00) from 11 to 24,6 to 30 and 15 


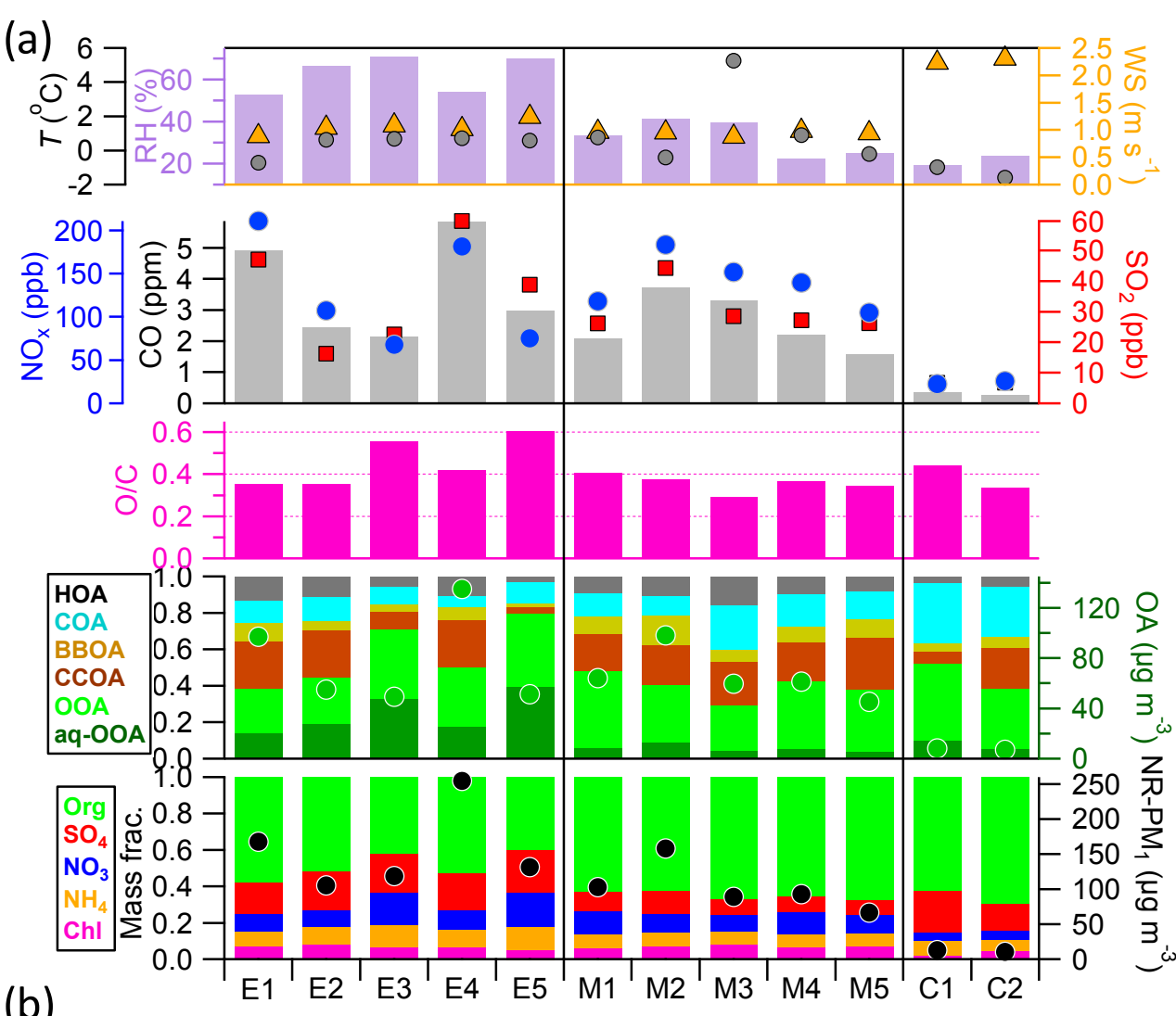

(b)

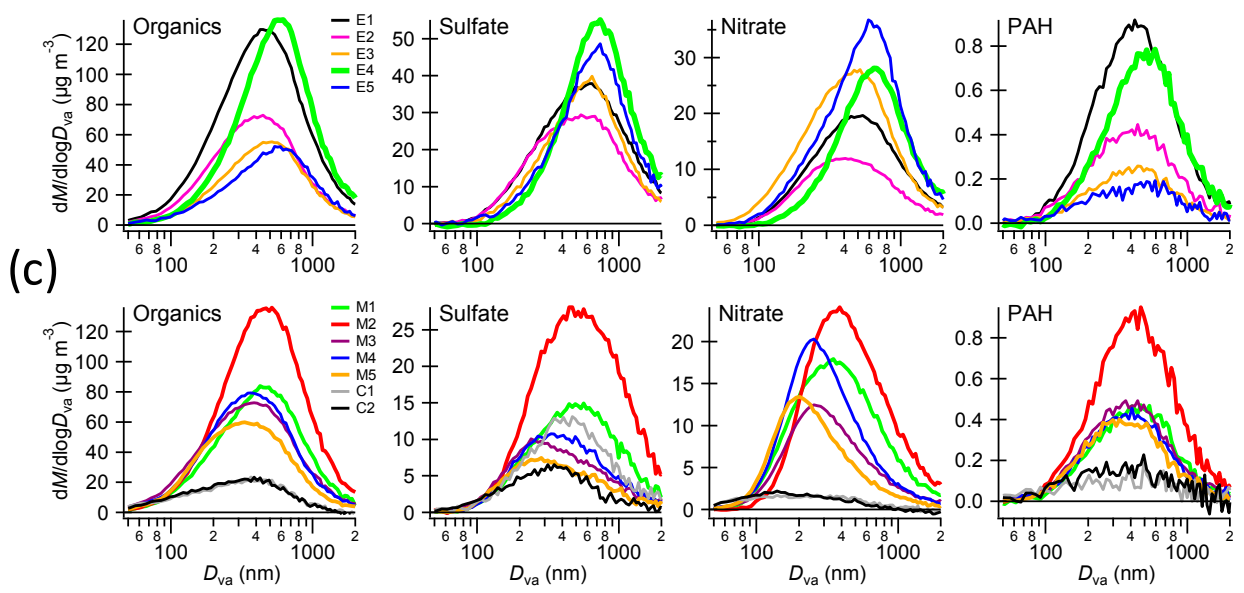

Figure 12. Summary of (a) meteorological conditions, gaseous species, $\mathrm{O} / \mathrm{C}, \mathrm{OA}$ composition and NR-PM 1 composition, and size distributions of organics, sulfate, nitrate and chloride for episodes (b) E1-E5 and (c) M1-M5 and C1-C2 in Fig. 1.

to $52 \mu \mathrm{g} \mathrm{m}^{-3}$, respectively. The size distributions of sulfate and nitrate also showed sudden changes, with the maximum diameters increasing from 370 to 600 and 260 to $500 \mathrm{~nm}$, respectively. The only explanation for such rapid changes is regional transport. As indicated in Fig. 14, the air mass trajectories changed from the north-west to the south by circulating through the west during the formation stage of E4. The MODIS satellite image indicated a clear dividing line of clean air and haze between the west-north-west and southeast, while the sampling site in the city is located on the line. Such a spatial distribution of haze was mainly caused by the topography of the North China Plain where Mount Taihang is in the west and Mount Yan is in the north. No doubt, the PM levels and composition can have significant changes when air masses switched between the two sides of the diving line. For example, the evolution of E4 was inter- 

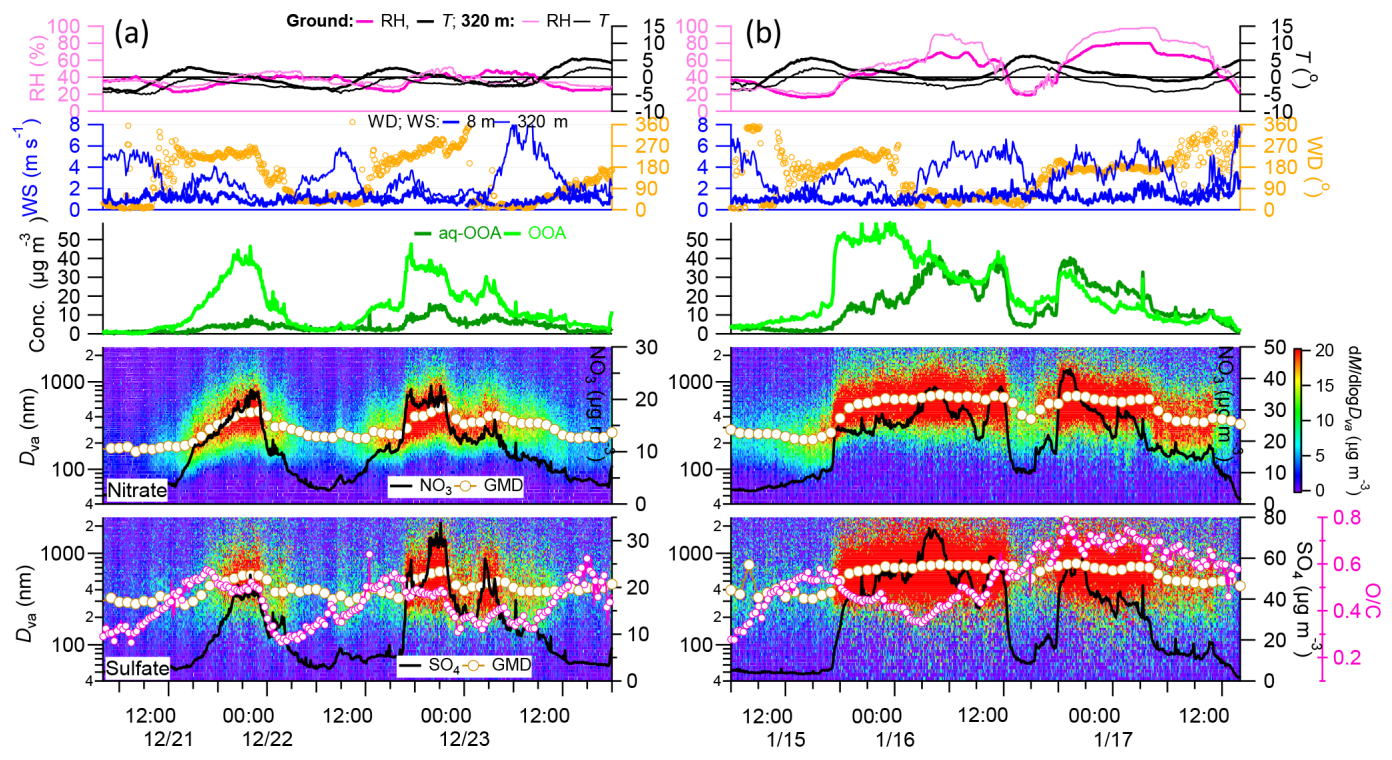

Figure 13. Evolution of meteorological parameters, SOA factors, $\mathrm{O} / \mathrm{C}$ ratios and size distributions of sulfate and nitrate during two different types of episodes. The $\mathrm{O} / \mathrm{C}$ ratios in the figures were calculated by excluding the contributions of COA.

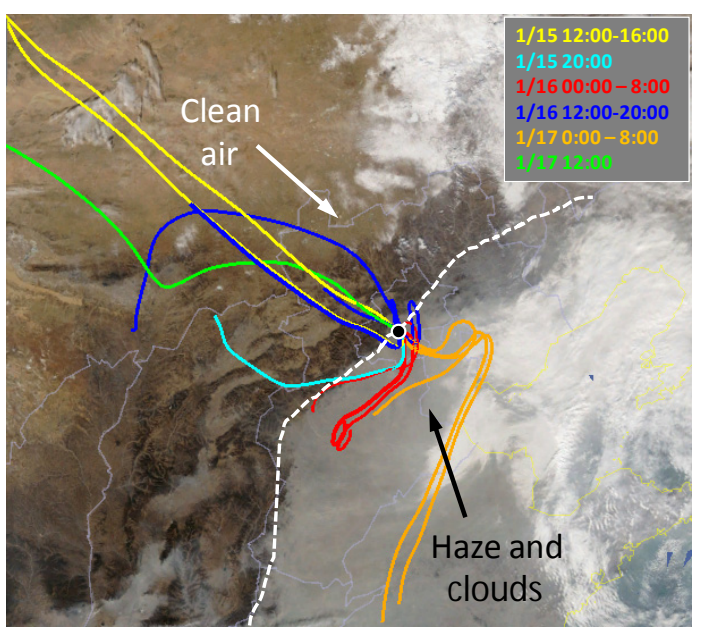

Figure 14. Two-day back-trajectories arriving at IAP, Beijing between 12:00 on 15 January and 12:00 on 17 January. The backtrajectories at $100 \mathrm{~m}$ height were calculated every $4 \mathrm{~h}$ using NOAA HYSPLIT Trajectory Model (http://www.ready.noaa.gov) (Stein et al., 2015). The background picture shows the image from the Moderate Resolution Imaging Spectroradiometer (MODIS) instrument on board the Aqua Satellite on 16 January. The white dashed line is an approximate dividing line between clean and haze regions.

rupted by a half-day clean period that was strongly associated with the north-western air masses (blue lines in Fig. 14). But the air pollution was changed back when air masses were switched to the south-east (orange lines in Fig. 14). While the concentration levels and size distributions of sulfate and nitrate remained relatively constant during E4, SOA showed substantial changes. OOA dominated SOA during the early stage of E4, yet aq-OOA increased gradually and was comparable to OOA. Such a change of SOA was consistent with the variations of RH and LWC. As RH and LWC increased, the contributions of aq-OOA increased correspondingly and even exceeded OOA during E5. This further demonstrated an increasing role of aq-OOA in PM pollution at high RH levels in winter. Consequently, OA became more oxidized during the evolution with $\mathrm{O} / \mathrm{C}$ ratios varying from $\sim 0.4$ to 0.8 .

\section{Conclusions}

We have a comprehensive characterization of submicron aerosol composition, size distributions, sources and processes of OA in the megacity of Beijing during winter 20132014. Submicron aerosol species varied dramatically across the entire study, largely due to meteorological changes, yet the bulk composition was consistent with previous winter studies, which was mainly composed of organics $(60 \%)$, sulfate $(15 \%)$ and nitrate $(11 \%)$. The size distributions varied differently among different aerosol species, particularly sulfate and nitrate peaked differently at $\sim 600$ and $\sim 300$ $400 \mathrm{~nm}$. The different diurnal cycles and RH dependence of sulfate and nitrate further illustrated their different formation mechanisms in winter, which is mainly driven by aq-phase processing and photochemical production, respectively.

The oxidation properties, sources and processes were investigated with elemental analysis and PMF. While the relatively low $\mathrm{O} / \mathrm{C}$ ratio suggested the less oxidized properties of OA, the diurnal cycle, by excluding the COA influence, showed a clear increase from 0.38 to 0.55 during the daytime, indicating photochemical production of SOA. 
In addition, we observed an evident increase of $\mathrm{O} / \mathrm{C}$ as a function of particle liquid water content at high $\mathrm{RH}$ levels (>50\%). Such a RH dependence of O / C was mainly caused by the increase of aq-OOA at high RH levels. These results indicate that aqueous-phase processing enhanced SOA production and oxidation states of $\mathrm{OA}$ as well in winter. PMF analysis of OA identified four primary sources, i.e. traffic, cooking, biomass burning and coal combustion, and two secondary factors. CCOA was the largest contributor of POA, on average accounting for $20 \%$, followed by COA (18\%). The CCOA spectrum showed distinct PAH signatures and was highly correlated with PAH $\left(r^{2}=0.92\right)$. BBOA showed a tight correlation with the tracer compound levoglucosan $\left(r^{2}=0.93\right)$. The average levoglucosan/BBOA ratio is 0.169 for the entire study, which might be used to estimate BBOA concentrations using molecular marker levoglucosan.

The two SOA factors showed largely different time and diurnal variations. While OOA was highly correlated with photochemical processing products (e.g. $\mathrm{O}_{x}, \mathrm{NO}_{3}$ and fragment ions of $\mathrm{CO}_{2}^{+}$), aq-OOA was strongly correlated with aqueous-phase processed products (e.g. liquid water content, sulfate and $\mathrm{S}$-containing ions, e.g. $\mathrm{CH}_{2} \mathrm{SO}_{2}^{+}$and $\mathrm{CH}_{3} \mathrm{SO}_{2}^{+}$). This result illustrated two different formation mechanisms in formation of SOA in winter. Although POA dominated OA for the entire study (56\%), episode analyses highlighted the more important role of SOA in OA (67-77\%) at high RH levels. Aerosol composition and size distributions can vary largely among different episodes, not only caused by different meteorological conditions, but also due to the air masses from different source regions. Particularly, the switching of air masses between north-west and south-south-east can lead to the rapid formation and cleaning of haze episodes.

\section{Data availability}

The observational data in this study are available from the authors upon request (sunyele@ mail.iap.ac.cn).

\section{The Supplement related to this article is available online at doi:10.5194/acp-16-8309-2016-supplement.}

Acknowledgements. This work was supported by the National Key Basic Research Program of China (2014CB447900; 2013CB955801), the National Natural Science Foundation of China (41575120; 41175108; 41475117), and the Strategic Priority Research Program (B) of the Chinese Academy of Sciences (XDB05020501). We thank Jean-Eudes Petit for providing a ZeFir toolkit to calculate bivariate polar plot.

Edited by: A. Ding

Reviewed by: two anonymous referees

\section{References}

Aiken, A. C., DeCarlo, P. F., Kroll, J. H., Worsnop, D. R., Huffman, J. A., Docherty, K. S., Ulbrich, I. M., Mohr, C., Kimmel, J. R., Sueper, D., Sun, Y., Zhang, Q., Trimborn, A., Northway, M., Ziemann, P. J., Canagaratna, M. R., Onasch, T. B., Alfarra, M. R., Prevot, A. S. H., Dommen, J., Duplissy, J., Metzger, A., Baltensperger, U., and Jimenez, J. L.: O / C and OM / OC ratios of primary, secondary, and ambient organic aerosols with HighResolution Time-of-Flight Aerosol Mass Spectrometry, Environ. Sci. Technol., 42, 4478-4485, 2008.

Aiken, A. C., Salcedo, D., Cubison, M. J., Huffman, J. A., DeCarlo, P. F., Ulbrich, I. M., Docherty, K. S., Sueper, D., Kimmel, J. R., Worsnop, D. R., Trimborn, A., Northway, M., Stone, E. A., Schauer, J. J., Volkamer, R. M., Fortner, E., de Foy, B., Wang, J., Laskin, A., Shutthanandan, V., Zheng, J., Zhang, R., Gaffney, J., Marley, N. A., Paredes-Miranda, G., Arnott, W. P., Molina, L. T., Sosa, G., and Jimenez, J. L.: Mexico City aerosol analysis during MILAGRO using high resolution aerosol mass spectrometry at the urban supersite (T0) - Part 1: Fine particle composition and organic source apportionment, Atmos. Chem. Phys., 9, 6633-6653, doi:10.5194/acp-9-6633-2009, 2009.

Allan, J. D., Williams, P. I., Morgan, W. T., Martin, C. L., Flynn, M. J., Lee, J., Nemitz, E., Phillips, G. J., Gallagher, M. W., and Coe, H.: Contributions from transport, solid fuel burning and cooking to primary organic aerosols in two UK cities, Atmos. Chem. Phys., 10, 647-668, doi:10.5194/acp-10-647-2010, 2010.

Altieri, K. E., Seitzinger, S. P., Carlton, A. G., Turpin, B. J., Klein, G. C., and Marshall, A. G.: Oligomers formed through in-cloud methylglyoxal reactions: Chemical composition, properties, and mechanisms investigated by ultra-high resolution FT-ICR mass spectrometry, Atmos. Environ., 42, 1476-1490, 2008.

Boström, C.-E., Gerde, P., Hanberg, A., Jernström, B., Johansson, C., Kyrklund, T., Rannug, A., Törnqvist, M., Victorin, K., and Westerholm, R.: Cancer risk assessment, indicators, and guidelines for polycyclic aromatic hydrocarbons in the ambient air, Environ. Health Perspect., 110, 451-488, 2002.

Canagaratna, M., Jayne, J., Jimenez, J. L., Allan, J. A., Alfarra, R., Zhang, Q., Onasch, T., Drewnick, F., Coe, H., Middlebrook, A., Delia, A., Williams, L., Trimborn, A., Northway, M., Kolb, C., Davidovits, P., and Worsnop, D.: Chemical and microphysical characterization of aerosols via Aerosol Mass Spectrometry, Mass Spectrom. Rev., 26, 185-222, 2007.

Canagaratna, M. R., Jayne, J. T., Ghertner, D. A., Herndon, S., Shi, Q., Jimenez, J. L., Silva, P. J., Williams, P., Lanni, T., Drewnick, F., Demerjian, K. L., Kolb, C. E., and Worsnop, D. R.: Chase studies of particulate emissions from in-use New York City vehicles, Aerosol Sci. Tech., 38, 555-573, 2004.

Canagaratna, M. R., Jimenez, J. L., Kroll, J. H., Chen, Q., Kessler, S. H., Massoli, P., Hildebrandt Ruiz, L., Fortner, E., Williams, L. R., Wilson, K. R., Surratt, J. D., Donahue, N. M., Jayne, J. T., and Worsnop, D. R.: Elemental ratio measurements of organic compounds using aerosol mass spectrometry: characterization, improved calibration, and implications, Atmos. Chem. Phys., 15, 253-272, doi:10.5194/acp-15-253-2015, 2015.

Cao, J., Xu, H., Xu, Q., Chen, B., and Kan, H.: Fine particulate matter constituents and cardiopulmonary mortality in a heavily polluted Chinese city, Environ. Health Perspect., 120, 373-378, 2012. 
Carlton, A. G., Turpin, B. J., Altieri, K. E., Seitzinger, S., Reff, A., Lim, H.-J., and Ervens, B.: Atmospheric oxalic acid and SOA production from glyoxal: Results of aqueous photooxidation experiments, Atmos. Environ., 41, 7588-7602, 2007.

Chen, Q., Heald, C. L., Jimenez, J. L., Canagaratna, M. R., Zhang, Q., He, L.-Y., Huang, X.-F., Campuzano-Jost, P., Palm, B. B., Poulain, L., Kuwata, M., Martin, S. T., Abbatt, J. P. D., Lee, A. K. Y., and Liggio, J.: Elemental Composition of Organic Aerosol: The Gap Between Ambient and Laboratory Measurements, Geophys. Res. Lett., 42, 4182-4189, doi:10.1002/2015GL063693, 2015.

Chen, Y., Sheng, G., Bi, X., Feng, Y., Mai, B., and Fu, J.: Emission factors for carbonaceous particles and polycyclic aromatic hydrocarbons from residential coal combustion in China, Environ. Sci. Technol., 39, 1861-1867, doi:10.1021/es0493650, 2005.

Cheng, Y., Engling, G., He, K.-B., Duan, F.-K., Ma, Y.-L., Du, Z.Y., Liu, J.-M., Zheng, M., and Weber, R. J.: Biomass burning contribution to Beijing aerosol, Atmos. Chem. Phys., 13, 77657781, doi:10.5194/acp-13-7765-2013, 2013.

Chhabra, P. S., Flagan, R. C., and Seinfeld, J. H.: Elemental analysis of chamber organic aerosol using an aerodyne high-resolution aerosol mass spectrometer, Atmos. Chem. Phys., 10, 4111-4131, doi:10.5194/acp-10-4111-2010, 2010.

Crippa, M., DeCarlo, P. F., Slowik, J. G., Mohr, C., Heringa, M. F., Chirico, R., Poulain, L., Freutel, F., Sciare, J., Cozic, J., Di Marco, C. F., Elsasser, M., Nicolas, J. B., Marchand, N., Abidi, E., Wiedensohler, A., Drewnick, F., Schneider, J., Borrmann, S., Nemitz, E., Zimmermann, R., Jaffrezo, J.-L., Prévôt, A. S. H., and Baltensperger, U.: Wintertime aerosol chemical composition and source apportionment of the organic fraction in the metropolitan area of Paris, Atmos. Chem. Phys., 13, 961-981, doi:10.5194/acp-13-961-2013, 2013.

DeCarlo, P. F., Ulbrich, I. M., Crounse, J., de Foy, B., Dunlea, E. J., Aiken, A. C., Knapp, D., Weinheimer, A. J., Campos, T., Wennberg, P. O., and Jimenez, J. L.: Investigation of the sources and processing of organic aerosol over the Central Mexican Plateau from aircraft measurements during MILAGRO, Atmos. Chem. Phys., 10, 5257-5280, doi:10.5194/acp-10-52572010, 2010.

De Haan, D. O., Corrigan, A. L., Smith, K. W., Stroik, D. R., Turley, J. J., Lee, F. E., Tolbert, M. A., Jimenez, J. L., Cordova, K. E., and Ferrell, G. R.: Secondary Organic Aerosol-Forming Reactions of Glyoxal with Amino Acids, Environ. Sci. Technol., 43, 28182824, doi:10.1021/es803534f, 2009.

De Haan, D. O., Hawkins, L. N., Kononenko, J. A., Turley, J. J., Corrigan, A. L., Tolbert, M. A., and Jimenez, J. L.: Formation of Nitrogen-Containing Oligomers by Methylglyoxal and Amines in Simulated Evaporating Cloud Droplets, Environ. Sci. Technol., 45, 984-991, doi:10.1021/es102933x, 2010.

Ding, A. J., Fu, C. B., Yang, X. Q., Sun, J. N., Petäjä, T., Kerminen, V.-M., Wang, T., Xie, Y., Herrmann, E., Zheng, L. F., Nie, W., Liu, Q., Wei, X. L., and Kulmala, M.: Intense atmospheric pollution modifies weather: a case of mixed biomass burning with fossil fuel combustion pollution in eastern China, Atmos. Chem. Phys., 13, 10545-10554, doi:10.5194/acp-13-10545-2013, 2013.

Ding, A. J., Huang, X., Nie, W., Sun, J. N., Kerminen, V. M., Petäjä, T., Su, H., Cheng, Y. F., Yang, X. Q., Wang, M. H., Chi, X. G., Wang, J. P., Virkkula, A., Guo, W. D., Yuan, J., Wang, S. Y., Zhang, R. J., Wu, Y. F., Song, Y., Zhu, T., Zilitinkevich, S., Kul- mala, M., and Fu, C. B.: Enhanced haze pollution by black carbon in megacities in China, Geophys. Res. Lett., 43, 2873-2879, doi:10.1002/2016GL067745, 2016.

Dzepina, K., Arey, J., Marr, L. C., Worsnop, D. R., Salcedo, D., Zhang, Q., Onasch, T. B., Molina, L. T., Molina, M. J., and Jimenez, J. L.: Detection of particle-phase polycyclic aromatic hydrocarbons in Mexico City using an aerosol mass spectrometer, Int. J. Mass Spectrom., 263, 152-170, 2007.

Elser, M., Huang, R.-J., Wolf, R., Slowik, J. G., Wang, Q., Canonaco, F., Li, G., Bozzetti, C., Daellenbach, K. R., Huang, Y., Zhang, R., Li, Z., Cao, J., Baltensperger, U., El-Haddad, I., and Prévôt, A. S. H.: New insights into $\mathrm{PM}_{2.5}$ chemical composition and sources in two major cities in China during extreme haze events using aerosol mass spectrometry, Atmos. Chem. Phys., 16, 3207-3225, doi:10.5194/acp-16-3207-2016, 2016.

Fountoukis, C. and Nenes, A.: ISORROPIA II: a computationally efficient thermodynamic equilibrium model for $\mathrm{K}^{+}$$\mathrm{Ca}^{2+}-\mathrm{Mg}^{2+}-\mathrm{NH}_{4}^{+}-\mathrm{Na}^{+}-\mathrm{SO}_{4}^{2-}-\mathrm{NO}_{3}^{-}-\mathrm{Cl}^{-}-\mathrm{H}_{2} \mathrm{O}$ aerosols, Atmos. Chem. Phys., 7, 4639-4659, doi:10.5194/acp-7-4639-2007, 2007.

Fröhlich, R., Crenn, V., Setyan, A., Belis, C. A., Canonaco, F., Favez, O., Riffault, V., Slowik, J. G., Aas, W., Aijälä, M., Alastuey, A., Artiñano, B., Bonnaire, N., Bozzetti, C., Bressi, M., Carbone, C., Coz, E., Croteau, P. L., Cubison, M. J., Esser-Gietl, J. K., Green, D. C., Gros, V., Heikkinen, L., Herrmann, H., Jayne, J. T., Lunder, C. R., Minguillón, M. C., Mocnik, G., O’Dowd, C. D., Ovadnevaite, J., Petralia, E., Poulain, L., Priestman, M., Ripoll, A., Sarda-Estève, R., Wiedensohler, A., Baltensperger, U., Sciare, J., and Prévôt, A. S. H.: ACTRIS ACSM intercomparison - Part 2: Intercomparison of ME-2 organic source apportionment results from 15 individual, co-located aerosol mass spectrometers, Atmos. Meas. Tech., 8, 2555-2576, doi:10.5194/amt8-2555-2015, 2015.

Fu, P., Kawamura, K., Okuzawa, K., Aggarwal, S. G., Wang, G., Kanaya, Y., and Wang, Z.: Organic molecular compositions and temporal variations of summertime mountain aerosols over Mt. Tai, North China Plain, J. Geophys. Res., 113, D19107, doi:10.1029/2008jd009900, 2008.

Ge, X., Wexler, A. S., and Clegg, S. L.: Atmospheric Amines Part II. Thermodynamic properties and gas/particle partitioning, Atmos. Environ., 45, 561-577, 2011.

Ge, X., Setyan, A., Sun, Y., and Zhang, Q.: Primary and secondary organic aerosols in Fresno, California during wintertime: Results from high resolution aerosol mass spectrometry, J. Geophys. Res., 117, D19301, doi:10.1029/2012JD018026, 2012a.

Ge, X., Zhang, Q., Sun, Y., Ruehl, C. R., and Setyan, A.: Effect of aqueous-phase processing on aerosol chemistry and size distributions in Fresno, California, during wintertime, Environ. Chem., 9, 221-235, 2012b.

Han, S., Kondo, Y., Oshima, N., Takegawa, N., Miyazaki, Y., Hu, M., Lin, P., Deng, Z., Zhao, Y., Sugimoto, N., and Wu, Y.: Temporal variations of elemental carbon in Beijing, J. Geophys. Res., 114, D23202, doi:10.1029/2009JD012027, 2009.

He, H., Wang, Y., Ma, Q., Ma, J., Chu, B., Ji, D., Tang, G., Liu, C., Zhang, H., and Hao, J.: Mineral dust and $\mathrm{NO}_{x}$ promote the conversion of $\mathrm{SO}_{2}$ to sulfate in heavy pollution days, Sci. Rep., 4, 4172, doi:10.1038/srep04172, 2014.

He, L.-Y., Lin, Y., Huang, X.-F., Guo, S., Xue, L., Su, Q., Hu, M., Luan, S.-J., and Zhang, Y.-H.: Characterization of high- 
resolution aerosol mass spectra of primary organic aerosol emissions from Chinese cooking and biomass burning, Atmos. Chem. Phys., 10, 11535-11543, doi:10.5194/acp-10-11535-2010, 2010.

He, L.-Y., Huang, X.-F., Xue, L., Hu, M., Lin, Y., Zheng, J., Zhang, R., and Zhang, Y.-H.: Submicron aerosol analysis and organic source apportionment in an urban atmosphere in Pearl River Delta of China using high-resolution aerosol mass spectrometry, J. Geophys. Res., 116, D12304, doi:10.1029/2010jd014566, 2011.

Hu, W., Hu, M., Hu, W., Jimenez, J. L., Yuan, B., Chen, W., Wang, M., Wu, Y., Chen, C., Wang, Z., Peng, J., Zeng, L., and Shao, M.: Chemical composition, sources and aging process of submicron aerosols in Beijing: contrast between summer and winter, J. Geophys. Res., 121, 1955-1977, doi:10.1002/2015JD024020, 2016.

Hu, W. W., Hu, M., Yuan, B., Jimenez, J. L., Tang, Q., Peng, J. F., Hu, W., Shao, M., Wang, M., Zeng, L. M., Wu, Y. S., Gong, Z. H., Huang, X. F., and He, L. Y.: Insights on organic aerosol aging and the influence of coal combustion at a regional receptor site of central eastern China, Atmos. Chem. Phys., 13, 10095-10112, doi:10.5194/acp-13-10095-2013, 2013.

Huang, R.-J., Zhang, Y., Bozzetti, C., Ho, K.-F., Cao, J.-J., Han, Y., Daellenbach, K. R., Slowik, J. G., Platt, S. M., Canonaco, F., Zotter, P., Wolf, R., Pieber, S. M., Bruns, E. A., Crippa, M., Ciarelli, G., Piazzalunga, A., Schwikowski, M., Abbaszade, G., SchnelleKreis, J., Zimmermann, R., An, Z., Szidat, S., Baltensperger, U., Haddad, I. E., and Prevot, A. S. H.: High secondary aerosol contribution to particulate pollution during haze events in China, Nature, 514, 218-222, doi:10.1038/nature13774, 2014.

Huang, X.-F., He, L.-Y., Hu, M., Canagaratna, M. R., Sun, Y., Zhang, Q., Zhu, T., Xue, L., Zeng, L.-W., Liu, X.-G., Zhang, Y.-H., Jayne, J. T., Ng, N. L., and Worsnop, D. R.: Highly time-resolved chemical characterization of atmospheric submicron particles during 2008 Beijing Olympic Games using an Aerodyne High-Resolution Aerosol Mass Spectrometer, Atmos. Chem. Phys., 10, 8933-8945, doi:10.5194/acp-10-8933-2010, 2010.

Huang, X.-F., He, L.-Y., Hu, M., Canagaratna, M. R., Kroll, J. H., Ng, N. L., Zhang, Y.-H., Lin, Y., Xue, L., Sun, T.-L., Liu, X.-G., Shao, M., Jayne, J. T., and Worsnop, D. R.: Characterization of submicron aerosols at a rural site in Pearl River Delta of China using an Aerodyne High-Resolution Aerosol Mass Spectrometer, Atmos. Chem. Phys., 11, 1865-1877, doi:10.5194/acp-11-18652011, 2011.

Jayne, J. T., Leard, D. C., Zhang, X., Davidovits, P., Smith, K. A., Kolb, C. E., and Worsnop, D. R.: Development of an aerosol mass spectrometer for size and composition analysis of submicron particles, Aerosol Sci. Tech., 33, 49-70, 2000.

Jiang, Q., Sun, Y. L., Wang, Z., and Yin, Y.: Aerosol composition and sources during the Chinese Spring Festival: fireworks, secondary aerosol, and holiday effects, Atmos. Chem. Phys., 15, 6023-6034, doi:10.5194/acp-15-6023-2015, 2015.

Jimenez, J. L., Jayne, J. T., Shi, Q., Kolb, C. E., Worsnop, D. R., Yourshaw, I., Seinfeld, J. H., Flagan, R. C., Zhang, X., Smith, K. A., Morris, J. W., and Davidovits, P.: Ambient aerosol sampling with an Aerosol Mass Spectrometer, J. Geophys. Res.-Atmos., 108, 8425, doi:10:1029/2001JD001213, 2003.

Kulmala, M., Lappalainen, H. K., Petäjä, T., Kurten, T., Kerminen, V.-M., Viisanen, Y., Hari, P., Sorvari, S., Bäck, J.,
Bondur, V., Kasimov, N., Kotlyakov, V., Matvienko, G., Baklanov, A., Guo, H. D., Ding, A., Hansson, H.-C., and Zilitinkevich, S.: Introduction: The Pan-Eurasian Experiment (PEEX) multidisciplinary, multiscale and multicomponent research and capacity-building initiative, Atmos. Chem. Phys., 15, 1308513096, doi:10.5194/acp-15-13085-2015, 2015.

Lanz, V. A., Alfarra, M. R., Baltensperger, U., Buchmann, B., Hueglin, C., and Prévôt, A. S. H.: Source apportionment of submicron organic aerosols at an urban site by factor analytical modelling of aerosol mass spectra, Atmos. Chem. Phys., 7, 15031522, doi:10.5194/acp-7-1503-2007, 2007.

Laskin, A., Smith, J. S., and Laskin, J.: Molecular characterization of nitrogen-containing organic compounds in biomass burning aerosols using high-resolution mass spectrometry, Environ. Sci. Technol., 43, 3764-3771, doi:10.1021/es803456n, 2009.

Lelieveld, J., Evans, J. S., Fnais, M., Giannadaki, D., and Pozzer, A.: The contribution of outdoor air pollution sources to premature mortality on a global scale, Nature, 525, 367-371, doi:10.1038/nature15371, 2015.

Li, P., Yan, R., Yu, S., Wang, S., Liu, W., and Bao, H.: Reinstate regional transport of $\mathrm{PM}_{2.5}$ as a major cause of severe haze in Beijing, P. Natl. Acad. Sci. USA, 112, E2739-E2740, doi:10.1073/pnas.1502596112, 2015.

Liang, X., Zou, T., Guo, B., Li, S., Zhang, H., Zhang, S., Huang, H., and Chen, S. X.: Assessing Beijing's $\mathrm{PM}_{2.5}$ pollution: severity, weather impact, APEC and winter heating, P. Roy. Soc. A-Math. Phy., 471, 20150257, doi:10.1098/rspa.2015.0257, 2015.

Lin, G., Sillman, S., Penner, J. E., and Ito, A.: Global modeling of SOA: the use of different mechanisms for aqueous-phase formation, Atmos. Chem. Phys., 14, 5451-5475, doi:10.5194/acp-145451-2014, 2014.

Liu, X. G., Li, J., Qu, Y., Han, T., Hou, L., Gu, J., Chen, C., Yang, Y., Liu, X., Yang, T., Zhang, Y., Tian, H., and Hu, M.: Formation and evolution mechanism of regional haze: a case study in the megacity Beijing, China, Atmos. Chem. Phys., 13, 4501-4514, doi:10.5194/acp-13-4501-2013, 2013.

Liu, Z., Hu, B., Wang, L., Wu, F., Gao, W., and Wang, Y.: Seasonal and diurnal variation in particulate matter $\left(\mathrm{PM}_{10}\right.$ and $\left.\mathrm{PM}_{2.5}\right)$ at an urban site of Beijing: analyses from a 9-year study, Environ. Sci. Pollut. R., 22, 627-642, doi:10.1007/s11356-014-33470, 2015.

Madaniyazi, L., Nagashima, T., Guo, Y., Yu, W., and Tong, S.: Projecting Fine Particulate Matter-Related Mortality in East China, Environ. Sci. Technol., 49, 11141-11150, doi:10.1021/acs.est.5b01478, 2015.

Matthew, B. M., Middlebrook, A. M., and Onasch, T. B.: Collection efficiencies in an Aerodyne Aerosol Mass Spectrometer as a function of particle phase for paboratory generated aerosols, Aerosol Sci. Tech., 42, 884-898, 2008.

Middlebrook, A. M., Bahreini, R., Jimenez, J. L., and Canagaratna, M. R.: Evaluation of composition-dependent collection efficiencies for the Aerodyne Aerosol Mass Spectrometer using field data, Aerosol Sci. Tech., 46, 258-271, 2012.

Mohr, C., Huffman, J. A., Cubison, M. J., Aiken, A. C., Docherty, K. S., Kimmel, J. R., Ulbrich, I. M., Hannigan, M., and Jimenez, J. L.: Characterization of primary organic aerosol emissions from meat cooking, trash burning, and motor vehicles with HighResolution Aerosol Mass Spectrometry and comparison with 
ambient and chamber observations, Environ. Sci. Technol., 43, 2443-2449, doi:10.1021/es8011518, 2009.

Mohr, C., DeCarlo, P. F., Heringa, M. F., Chirico, R., Slowik, J. G., Richter, R., Reche, C., Alastuey, A., Querol, X., Seco, R., Peñuelas, J., Jiménez, J. L., Crippa, M., Zimmermann, R., Baltensperger, U., and Prévôt, A. S. H.: Identification and quantification of organic aerosol from cooking and other sources in Barcelona using aerosol mass spectrometer data, Atmos. Chem. Phys., 12, 1649-1665, doi:10.5194/acp-12-1649-2012, 2012.

Nenes, A., Pandis, S. N., and Pilinis, C.: ISORROPIA: A new thermodynamic equilibrium model for multiphase multicomponent inorganic aerosols, Aquat. Geochem., 4, 123-152, 1998.

Ng, N. L., Canagaratna, M. R., Jimenez, J. L., Zhang, Q., U1brich, I. M., and Worsnop, D. R.: Real-time methods for estimating organic component mass concentrations from Aerosol Mass Spectrometer data, Environ. Sci. Technol., 45, 910-916, doi:10.1021/es102951k, 2011.

Okuda, T., Naoi, D., Tenmoku, M., Tanaka, S., He, K., Ma, Y., Yang, F., Lei, Y., Jia, Y., and Zhang, D.: Polycyclic aromatic hydrocarbons (PAHs) in the aerosol in Beijing, China, measured by aminopropylsilane chemically-bonded stationary-phase column chromatography and HPLC/fluorescence detection, Chemosphere, 65, 427-435, 2006.

Paatero, P. and Tapper, U.: Positive matrix factorization: A nonnegative factor model with optimal utilization of error estimates of data values, Environmetrics, 5, 111-126, 1994.

Petäjä, T., Järvi, L., Kerminen, V. M., Ding, A. J., Sun, J. N., Nie, W., Kujansuu, J., Virkkula, A., Yang, X., Fu, C. B., Zilitinkevich, S., and Kulmala, M.: Enhanced air pollution via aerosol-boundary layer feedback in China, Sci. Rep., 6, 18998, doi:10.1038/srep18998, 2016.

Quan, J., Liu, Q., Li, X., Gao, Y., Jia, X., Sheng, J., and Liu, Y.: Effect of heterogeneous aqueous reactions on the secondary formation of inorganic aerosols during haze events, Atmos. Environ., $122,306-312,2015$

Simoneit, B. R. T.: Biomass burning - a review of organic tracers for smoke from incomplete combustion, Appl. Geochem., 17, 129162,2002

Stein, A. F., Draxler, R. R., Rolph, G. D., Stunder, B. J. B., Cohen, M. D., and Ngan, F.: NOAA's HYSPLIT Atmospheric Transport and Dispersion Modeling System, B. Am. Meteorol. Soc., 96, 2059-2077, doi:10.1175/BAMS-D-14-00110.1, 2015.

Sueper, D.: ToF-AMS Analysis Software, available at: http://cires.colorado.edu/jimenez-group/ToFAMSResources/ ToFSoftware/index.html, last access: 1 December 2014.

Sullivan, A. P., Holden, A. S., Patterson, L. A., McMeeking, G. R., Kreidenweis, S. M., Malm, W. C., Hao, W. M., Wold, C. E., and Collett, J. L., Jr.: A method for smoke marker measurements and its potential application for determining the contribution of biomass burning from wildfires and prescribed fires to ambient $\mathrm{PM}_{2.5}$ organic carbon, J. Geophys. Res., 113, D22302, doi:10.1029/2008jd010216, 2008.

Sun, J., Zhang, Q., Canagaratna, M. R., Zhang, Y., Ng, N. L., Sun, Y., Jayne, J. T., Zhang, X., Zhang, X., and Worsnop, D. R.: Highly time- and size-resolved characterization of submicron aerosol particles in Beijing using an Aerodyne Aerosol Mass Spectrometer, Atmos. Environ., 44, 131-140, 2010.

Sun, Y. L., Zhang, Q., Anastasio, C., and Sun, J.: Insights into secondary organic aerosol formed via aqueous-phase reactions of phenolic compounds based on high resolution mass spectrometry, Atmos. Chem. Phys., 10, 4809-4822, doi:10.5194/acp-104809-2010, 2010.

Sun, Y.-L., Zhang, Q., Schwab, J. J., Demerjian, K. L., Chen, W.N., Bae, M.-S., Hung, H.-M., Hogrefe, O., Frank, B., Rattigan, O. V., and Lin, Y.-C.: Characterization of the sources and processes of organic and inorganic aerosols in New York city with a high-resolution time-of-flight aerosol mass apectrometer, Atmos. Chem. Phys., 11, 1581-1602, doi:10.5194/acp-11-15812011, 2011.

Sun, Y. L., Wang, Z., Dong, H., Yang, T., Li, J., Pan, X., Chen, P., and Jayne, J. T.: Characterization of summer organic and inorganic aerosols in Beijing, China with an Aerosol Chemical Speciation Monitor, Atmos. Environ., 51, 250-259, doi:10.1016/j.atmosenv.2012.01.013, 2012.

Sun, Y. L., Wang, Z., Fu, P., Jiang, Q., Yang, T., Li, J., and Ge, $\mathrm{X}$.: The impact of relative humidity on aerosol composition and evolution processes during wintertime in Beijing, China, Atmos. Environ., 77, 927-934, 2013a.

Sun, Y. L., Wang, Z. F., Fu, P. Q., Yang, T., Jiang, Q., Dong, H. B., Li, J., and Jia, J. J.: Aerosol composition, sources and processes during wintertime in Beijing, China, Atmos. Chem. Phys., 13, 4577-4592, doi:10.5194/acp-13-4577-2013, 2013 b.

Sun, Y. L., Jiang, Q., Wang, Z., Fu, P., Li, J., Yang, T., and Yin, Y.: Investigation of the sources and evolution processes of severe haze pollution in Beijing in January 2013, J. Geophys. Res., 119, 4380-4398, doi:10.1002/2014JD021641, 2014.

Sun, Y. L., Wang, Z. F., Du, W., Zhang, Q., Wang, Q. Q., Fu, P. Q., Pan, X. L., Li, J., Jayne, J., and Worsnop, D. R.: Longterm real-time measurements of aerosol particle composition in Beijing, China: seasonal variations, meteorological effects, and source analysis, Atmos. Chem. Phys., 15, 10149-10165, doi:10.5194/acp-15-10149-2015, 2015.

Sun, Y. L., Wang, Z., Wild, O., Xu, W., Chen, C., Fu, P., Du, W., Zhou, L., Zhang, Q., Han, T., Wang, Q., Pan, X., Zheng, H., Li, J., Guo, X., Liu, J., and Worsnop, D. R.: "APEC Blue": Secondary Aerosol Reductions from Emission Controls in Beijing, Sci. Rep., 6, 20668, doi:10.1038/srep20668, 2016.

Tan, Y., Perri, M. J., Seitzinger, S. P., and Turpin, B. J.: Effects of Precursor Concentration and Acidic Sulfate in Aqueous Glyoxal-OH Radical Oxidation and Implications for Secondary Organic Aerosol, Environ. Sci. Technol., 43, 8105-8112, doi:10.1021/es901742f, 2009.

Tian, S. L., Pan, Y. P., and Wang, Y. S.: Size-resolved source apportionment of particulate matter in urban Beijing during haze and non-haze episodes, Atmos. Chem. Phys., 16, 1-19, doi:10.5194/acp-16-1-2016, 2016.

Turpin, B. J. and Lim, H. J.: Species contributions to $\mathrm{PM}_{2.5}$ mass concentrations: Revisiting common assumptions for estimating organic mass, Aerosol Sci. Tech., 35, 602-610, 2001.

Ulbrich, I. M., Canagaratna, M. R., Zhang, Q., Worsnop, D. R., and Jimenez, J. L.: Interpretation of organic components from Positive Matrix Factorization of aerosol mass spectrometric data, Atmos. Chem. Phys., 9, 2891-2918, doi:10.5194/acp-9-2891-2009, 2009.

Wang, Q., Sun, Y., Jiang, Q., Du, W., Sun, C., Fu, P., and Wang, Z.: Chemical composition of aerosol particles and light extinction apportionment before and during the heating sea- 
son in Beijing, China, J. Geophys. Res., 120, 12708-12722, doi:10.1002/2015JD023871, 2015.

Wang, Y., Yao, L., Wang, L., Liu, Z., Ji, D., Tang, G., Zhang, J., Sun, Y., Hu, B., and Xin, J.: Mechanism for the formation of the January 2013 heavy haze pollution episode over central and eastern China, Sci. China Earth Sci., 57, 14-25, doi:10.1007/s11430013-4773-4, 2014.

Wang, Z., Li, J., Wang, Z., Yang, W., Tang, X., Ge, B., Yan, P., Zhu, L., Chen, X., Chen, H., Wang, W., Li, J., Liu, B., Wang, X., Wand, W., Zhao, Y., Lu, N., and Su, D.: Modeling study of regional severe hazes over mid-eastern China in January 2013 and its implications on pollution prevention and control, Sci. China Earth Sci., 57, 3-13, doi:10.1007/s11430-013-4793-0, 2014.

Xie, Y., Ding, A., Nie, W., Mao, H., Qi, X., Huang, X., Xu, Z., Kerminen, V.-M., Petäjä, T., Chi, X., Virkkula, A., Boy, M., Xue, L., Guo, J., Sun, J., Yang, X., Kulmala, M., and Fu, C.: Enhanced sulfate formation by nitrogen dioxide: Implications from in-situ observations at the SORPES Station, J. Geophys. Res., 120, 12679-12694, doi:10.1002/2015JD023607, 2015.

Xu, J., Zhang, Q., Chen, M., Ge, X., Ren, J., and Qin, D.: Chemical composition, sources, and processes of urban aerosols during summertime in northwest China: insights from high-resolution aerosol mass spectrometry, Atmos. Chem. Phys., 14, 1259312611, doi:10.5194/acp-14-12593-2014, 2014.

Xu, J., Shi, J., Zhang, Q., Ge, X., Canonaco, F., Prévôt, A. S. H., Vonwiller, M., Szidat, S., Ge, J., Ma, J., An, Y., Kang, S., and Qin, D.: Wintertime organic and inorganic aerosols in Lanzhou, China: Sources, processes and comparison with the results during summer, Atmos. Chem. Phys. Discuss., doi:10.5194/acp2016-278, in review, 2016.

Xu, W. Q., Sun, Y. L., Chen, C., Du, W., Han, T. T., Wang, Q. Q., Fu, P. Q., Wang, Z. F., Zhao, X. J., Zhou, L. B., Ji, D. S., Wang, P. C., and Worsnop, D. R.: Aerosol composition, oxidation properties, and sources in Beijing: results from the 2014 Asia-Pacific Economic Cooperation summit study, Atmos. Chem. Phys., 15, 13681-13698, doi:10.5194/acp-15-13681-2015, 2015.

Yang, Y. R., Liu, X. G., Qu, Y., An, J. L., Jiang, R., Zhang, Y. H., Sun, Y. L., Wu, Z. J., Zhang, F., Xu, W. Q., and Ma, Q. X.: Characteristics and formation mechanism of continuous hazes in China: a case study during the autumn of 2014 in the North China Plain, Atmos. Chem. Phys., 15, 8165-8178, doi:10.5194/acp-158165-2015, 2015.

Zhang, H., Wang, S., Hao, J., Wang, X., Wang, S., Chai, F., and Li, M.: Air pollution and control action in Beijing, J. Clean. Prod., 112, 1519-1527, 2016.

Zhang, J. K., Sun, Y., Liu, Z. R., Ji, D. S., Hu, B., Liu, Q., and Wang, Y. S.: Characterization of submicron aerosols during a month of serious pollution in Beijing, 2013, Atmos. Chem. Phys., 14, 2887-2903, doi:10.5194/acp-14-2887-2014, 2014.

Zhang, J. K., Ji, D. S., Liu, Z. R., Hu, B., Wang, L. L., Huang, X. J., and Wang, Y. S.: New characteristics of submicron aerosols and factor analysis of combined organic and inorganic aerosol mass spectra during winter in Beijing, Atmos. Chem. Phys. Discuss., 15, 18537-18576, doi:10.5194/acpd-15-18537-2015, 2015a.

Zhang, J. K., Wang, L. L., Wang, Y. H., and Wang, Y. S.: Submicron aerosols during the Beijing Asia-Pacific Economic Cooperation conference in 2014, Atmos. Environ., 124, 224-231, 2016.
Zhang, Q., Worsnop, D. R., Canagaratna, M. R., and Jimenez, J. L.: Hydrocarbon-like and oxygenated organic aerosols in Pittsburgh: insights into sources and processes of organic aerosols, Atmos. Chem. Phys., 5, 3289-3311, doi:10.5194/acp-5-32892005, 2005.

Zhang, Q., Jimenez, J. L., Worsnop, D. R., and Canagaratna, M.: A case study of urban particle acidity and its effect on secondary organic aerosol, Environ. Sci. Technol., 41, 3213-3219, 2007.

Zhang, Q., Jimenez, J., Canagaratna, M., Ulbrich, I., Ng, N., Worsnop, D., and Sun, Y.: Understanding atmospheric organic aerosols via factor analysis of aerosol mass spectrometry: a review, Anal. Bioanal. Chem., 401, 3045-3067, doi:10.1007/s00216-011-5355-y, 2011.

Zhang, Q., He, K., and Huo, H.: Policy: Cleaning China's air, Nature, 484, 161-162, 2012.

Zhang, R., Jing, J., Tao, J., Hsu, S.-C., Wang, G., Cao, J., Lee, C. S. L., Zhu, L., Chen, Z., Zhao, Y., and Shen, Z.: Chemical characterization and source apportionment of $\mathrm{PM}_{2.5}$ in Beijing: seasonal perspective, Atmos. Chem. Phys., 13, 7053-7074, doi:10.5194/acp-13-7053-2013, 2013.

Zhang, Y., Schauer, J. J., Zhang, Y., Zeng, L., Wei, Y., Liu, Y., and Shao, M.: Characteristics of particulate carbon emissions from real-world Chinese coal combustion, Environ. Sci. Technol., 42, 5068-5073, 2008.

Zhao, B., Wang, S. X., Liu, H., Xu, J. Y., Fu, K., Klimont, Z., Hao, J. M., He, K. B., Cofala, J., and Amann, M.: $\mathrm{NO}_{x}$ emissions in China: historical trends and future perspectives, Atmos. Chem. Phys., 13, 9869-9897, doi:10.5194/acp-13-9869-2013, 2013.

Zhao, X. J., Zhao, P. S., Xu, J., Meng,, W., Pu, W. W., Dong, F., He, D., and Shi, Q. F.: Analysis of a winter regional haze event and its formation mechanism in the North China Plain, Atmos. Chem. Phys., 13, 5685-5696, doi:10.5194/acp-13-5685-2013, 2013.

Zhao, Y., Hu, M., Slanina, S., and Zhang, Y.: Chemical Compositions of Fine Particulate Organic Matter Emitted from Chinese Cooking, Environ. Sci. Technol., 41, 99-105, doi:10.1021/es0614518, 2006.

Zheng, G. J., Duan, F. K., Su, H., Ma, Y. L., Cheng, Y., Zheng, B., Zhang, Q., Huang, T., Kimoto, T., Chang, D., Pöschl, U., Cheng, Y. F., and He, K. B.: Exploring the severe winter haze in Beijing: the impact of synoptic weather, regional transport and heterogeneous reactions, Atmos. Chem. Phys., 15, 2969-2983, doi:10.5194/acp-15-2969-2015, 2015.

Zheng, M., Salmon, L. G., Schauer, J. J., Zeng, L., Kiang, C. S., Zhang, Y., and Cass, G. R.: Seasonal trends in $\mathrm{PM}_{2.5}$ source contributions in Beijing, China, Atmos. Environ., 39, 3967-3976, doi:10.1016/j.atmosenv.2005.03.036, 2005.

Zhou, W., Jiang, J., Duan, L., and Hao, J.: Evolution of submicron organic aerosols during a complete residential coal combustion process, Environ. Sci. Technol., doi:10.1021/acs.est.6b00075, online first, 2016.

Zorn, S. R., Drewnick, F., Schott, M., Hoffmann, T., and Borrmann, S.: Characterization of the South Atlantic marine boundary layer aerosol using an aerodyne aerosol mass spectrometer, Atmos. Chem. Phys., 8, 4711-4728, doi:10.5194/acp-8-47112008, 2008. 